BULLETIN Bulletin hispanique

HISPANIQUE Université Michel de Montaigne Bordeaux

$109-2 \mid 2007$

La formation du Parnasse espagnol XVe-XVIII ${ }^{\mathrm{e}}$ siècle

\title{
El Parnaso español en la historia literaria del siglo XVIII
}

Inmaculada Urzainqui

\section{OpenEdition}

Journals

Edición electrónica

URL: http://journals.openedition.org/bulletinhispanique/341

DOI: 10.4000/bulletinhispanique.341

ISSN: $1775-3821$

Editor

Presses universitaires de Bordeaux

Edición impresa

Fecha de publicación: 1 diciembre 2007

Paginación: 643-684

ISBN: 978-2-85276-096-7

ISSN: 0007-4640

Referencia electrónica

Inmaculada Urzainqui, "El Parnaso español en la historia literaria del siglo XVIII », Bulletin hispanique [En línea], 109-2 | 2007, documento 13, Publicado el 01 diciembre 2011, consultado el 01 mayo 2019 URL : http://journals.openedition.org/bulletinhispanique/341; DOI : 10.4000/bulletinhispanique.341 


\title{
El Parnaso español en la historia literaria del siglo XVIII
}

\author{
INMACULADA URZAINQUI \\ Universidad de Oviedo
}

C'est la littérature nationale, la littérature des Espagnols, qui constitue l'objet prioritaire de l'historiographie littéraire du XVIII siècle. Mais quels sont les termes et les critères qui permettent de fixer le cadre spécifique de cette littérature nationale? Qui sont ceux que le Parnasse accueille, et comment sont-ils évalués? La présente étude tente de répondre à ces questions en se fondant sur l'analyse de cinq des plus remarquables histoires littéraires des années 1700 (Sarmiento, L. J. Velázquez, les frères Mohedano, Lampillas, J. Andrés).

El frente prioritario de la historiografía literaria del XVIII lo constituye la literatura nacional, la literatura de los españoles. Pero, ¿en qué términos y con qué criterios se fija el peculiar marco de esa literatura nacional?, ¿quiénes son y cómo se valoran los integrantes de su Parnaso? El presente estudio trata de responder a estas preguntas mediante el análisis de cinco de las más notables historias literarias del setecientos (Sarmiento, L. J. Velázquez, hermanos Mohedano, Lampillas, J. Andrés).

The priority front of the literary historiography of the XVIIIth constitutes the national literature, the literature of the Spanish. But, in what terms and with what criteria can we fix the peculiar frame of the national literature?, Who are they and how are the members of its Parnassus valued? The present study tries to answer these questions through the analysis of five of the most remarkable literary histories out of the seven hundred (Sarmiento, L. J. Velazquez, the brothers Mohedano, Lampillas and J. Andrés).

Mots-clés: Histoire littéraire - Littérature nationale - Parnasse espagnol - Sarmiento - Velázquez - Mohedano - Lampillas - Andrés.

$B H i$, Tome 109, nº 2 - décembre 2007 - p. 643 à 684. 
$\mathrm{D}$ E ACUERDo con su significación común («Parnaso. El monte que los Mithológicos fingen que es habitación de las Musas: por lo que se suele tomar por el conjunto de los Poetas", Diccionario de Autoridades), es evidente que toda historia literaria es un Parnaso. Allí están, vistos en el proceso de la historia, los poetas de un pueblo, un género o un tiempo determinado. Lo que le singulariza frente a otro tipo de parnasos (antologías, repertorios bio-bibliográficos, colecciones, alegorías...) es el prisma de consideración: el historiador asciende al territorio de los poetas no para verlos en un presente estático -en un orden simultáneo-, sino para situarlos, caracterizarlos y valorarlos en el itinerario temporal de la literatura.

$Y$ ese es el enfoque que preside la innovadora tarea en la que se emplean notables intelectuales del siglo XVIII en el cauce de la renovación epistemológica que tiene lugar en la historiografía y los estudios literarios ${ }^{1}$. Porque aunque es cierto que antes se habían escrito diversas obras con informaciones históricas sobre la literatura -la Carta Prohemio del marqués de Santillana, el Diálogo de la Lengua de Valdés, el Canto del Turia de Gil Polo, el Discurso sobre la poesía castellana de Argote de Molina, el Laurel de Apolo de Lope, el Viaje del Parnaso cervantino...-, nunca antes se había conocido un empeño tan decidido por arrojar luz sobre la textualidad histórica, es decir, por reconstruir, ordenar y sistematizar, desde criterios cronológicos y estéticos, el perfil evolutivo de la literatura española. Además del genuino interés ilustrado por el conocimiento histórico ${ }^{2}$, principal motor que impulsa esa actividad, otros componentes del paisaje mental de la época jugaban a su favor, como la percepción del cambio y progreso de las artes, la toma de conciencia del sentido institucional y científico de lo literario, el fortalecimiento del sentimiento nacional con el consiguiente afán por redescubrir y defender los valores patrios frente a la incomprensión o el desprecio de los extranjeros ${ }^{3}$, la fe en el valor educativo de la historia

1. Sobre la actividad historiográfica del XVIII, vid. Frank Baasner, Literaturgeschichtsschreibung in Spanien von den Angängen bis 1868, Frankfurt Am Main, Vittorio Klostermann, 1995 y José Cebrián, «Historia literaria», en F. Aguilar Piñal (ed.), Historia literaria de España en el siglo XVIII, Madrid, Trotta-C.S.I.C., 1996, pp. 513-592.

2. Para el conocimiento del valor que se asigna a la Historia como medio de comprensión de la realidad y cimiento del progreso, sigue siendo fundamental el estudio de José Antonio Maravall «Mentalidad burguesa e idea de la Historia en el siglo XVIII», Revista de Occidente, no 107 (1972), pp. 250-286 (reed. en Estudios de la historia del pensamiento español (siglo XVIII), ed. Carmen Iglesias, Madrid, Biblioteca Mondadori, 1991, pp. 113-138).

3. La influencia de esta actitud -ya subrayada por Sarrailh, Domínguez Ortiz, J. Marías, Maravall y otros- en la historiografía literaria, la puso de manifiesto José Carlos Mainer en su importante estudio sobre "La invención de la literatura española» (Literaturas regionales en España, eds. J. M. Enguita y J. C. Mainer, Zaragoza, Institución Fernando el Católico, 
para fundamentar el juicio estético y promover el buen gusto, etc. Porque en efecto, la reconstrucción del pasado literario no sólo es sentida como pieza inherente de esa historia total que preconiza la historiografía moderna ${ }^{4}$; supone también configurar un escenario discursivo idóneo para pensar la literatura integrando el análisis de su decurso en el sistema de conocimientos, penetrar en las causas de su situación actual, forjar una tradición que refleje la identidad nacional y sea un referente en la educación humanística, resituar la teoría literaria desde el dinamismo de la historia y, en fin, expresar el compromiso con la mejora y dignificación del arte literario poniendo a la vista, diacrónica y razonadamente, sus miserias y sus grandezas. El historiador de la literatura tendrá que hacer, sí, el censo de población del Parnaso; pero, si desempeńa su cometido con sentido crítico y pedagógico -según aspiración común entonces-, tratando de identificar y asignar sentido, estético y ejemplarizante, a los vaivenes artísticos y colocando a cada autor en el lugar que le corresponda según sus méritos. Por eso la historia literaria del setecientos, como la de cualquier época, en tanto que sistema de valores ligado a unos intereses ideológicos y a una determinada forma de entender el hecho literario, tiene un papel fundamental en la construcción y fijación del canon ${ }^{5}$.

1994, pp. 23-45) y la ha analizado monográficamente Joaquín Álvarez Barrientos en «Nación e historia literaria a mediados del siglo XVIII en España», en Historia literaria / Historia de la literatura, ed. Leonardo Romero Tobar, Zaragoza, Prensas Universitarias de Zaragoza, 2004, pp. 101-114.

4. Como se refleja en la queja de Sarmiento ante las carencias de la historiografía tradicional: «Si tomo un libro de Historia en la mano, no tropiezo con otra cosa sino con un texido continuado de guerras, con una fastidiosa repetición de oraciones que jamás han dicho los capitanes, y cuando más, con tal cual nacimiento, casamiento y muerte de príncipes, como si sólo las acciones de éstos fuesen el único objeto de la Historia. Ésta debe instruir a los hombres, presentándoles los sucesos más memorables, no sólo belicosos, sino también físicos, cosmográficos, políticos, morales, theológicos y literarios» (Obras póstumas del Rmo. P. M. Fr. Martín Sarmiento, benedictino. Tomo Primero. Memorias para la historia de la poesía y poetas españoles: dadas a luz por el Monasterio de S. Martín de Madrid, Madrid, Joaquín Ibarra, 1775, p. 7).

5. Como han subrayado, en contextos analíticos diversos, J. C. Mainer («Sobre el canon de la literatura española del siglo XX", en El canon literario, ed. E. Sullá, Madrid, Arco/Libros, 1988, pp. 271-299), Claudio Guillén (Múltiples moradas. Ensayo de literatura comparada, Barcelona, Tusquets, 1998), Leonardo Romero Tobar («Las historias de la literatura y la fabricación del canon", en Cànon literari: ordre i subversió, ed. J. Pont y J. M. Sala Valldaura, Lleida, Institut d'Estudis Ilerdencs, 1998, pp.47-64), y José María Pozuelo Yvanco y Rosa María Aradra Sánchez (Teoría del canon y la literatura española, Madrid, Cátedra, 2000). Para una panorámica de conjunto sobre el canon dieciochesco y la significación de la historiografía literaria, vid. la segunda parte de este libro, redactada por R. M. Aradra: «El canon en la literatura española (siglos XVIII y XIX)», pp. 141-290. También, los artículos de Guillermo 
Obviamente, lo primero que esos historiadores tuvieron que determinar, con independencia del concepto que cada uno tuviera de lo literario y del método más a propósito para su trabajo ${ }^{6}$, fue el ámbito de la literatura que querían abarcar pues, como escribió hace años Oscar Tacca, «el ordenamiento dela historia literaria supone la solución de un problema previo: la delimitación o circunscripción del área cuyo estudio va a intentarse» ${ }^{7}$. Y en este punto la unanimidad es prácticamente absoluta, pues salvo el Origen, progresos y estado actual de toda la literatura de Juan Andrés, que encara ambiciosamente toda la producción literaria universal, englobada en el conjunto más amplio del proceso cultural, el frente prioritario de esta naciente historiografía lo constituye -con el perfil concreto que cada uno quiera imponerse (visiones generales, de una época, un género, etc.)- la literatura nacional, la literatura de los españoles, como entidad autónoma y distinta de todas las demás ${ }^{8}$.

Pero, ¿qué es para ellos la literatura española? O dicho de otra manera, ¿en qué términos y con qué criterios fijan el peculiar marco de la literatura nacional?

Enfrentados a tal proyecto, podían optar por dos posibilidades básicas, cada una de las cuales implicaba problemas epistemológicos y conducía a tareas y construcciones discursivas - parnasos- diferentes. Con un criterio estrictamente histórico, la historia literaria suponía indagar en todas las manifestaciones literarias de la «nación» española, una palabra que va a experimentar en el Siglo de las Luces un importante cambio semántico, pues de su significación primaria (del latín natio) como el conjunto de los

Carnero, («Sobre el canon literario español dieciochesco», en Ínsula, no 600, 1996, pp. 7-9) y José Checa Beltrán ("En busca del canon perdido: el siglo XVIII», en Studi Ispanici, 2002, pp. 95-115).

6. Me he ocupado de ambas cuestiones en «La construcción de la historia de la literatura en el siglo XVIII: ¿qué literatura?», en Literatura-Cultura-Media-Lengua. Nuevos planteamientos de la investigación del siglo XVIII en España e Hispanoamérica, eds. Christian von Tschilschke I Andreas Gelz, Frankfurt am Main-Berlin-Bern-Bruxelles-New York-Oxford-Wien, Peter Lang Europäischer Verlag der Wissenschaften, 2005, pp. 47-63 y «Hacia una teoría de la historia literaria en el siglo XVIII: competencias del historiador», en Historia literaria / Historia de la literatura, ed. Leonardo Romero Tobar, Zaragoza, Prensas Universitarias de Zaragoza, 2004, pp. 209-236.

7. Oscar Tacca, La historia literaria; Madrid, Gredos, 1968, p. 77.

8. Lo que no obsta para que se redacten también notables repertorios bio-bibliográficos de carácter local o regional, como Escritores del Reyno de Valencia (1747-1749) de Vicente Ximeno, Biblioteca asturiana (1781) de Carlos González de Posada, Hijos de Madrid ilustres (1789-1791) de José Antonio Álvarez y Baena, Biblioteca antigua y nueva de los escritores aragoneses (1796-1798) de Félix Latassa, etc. 
habitantes de un país («la colección de los habitadores de alguna provincia, país o reino", Diccionario de Autoridades) va a pasar a designar una comunidad política signada por la sujeción a un mismo soberano y a unas mismas leyes, tal como refleja Feijoo y definirá tiempo después Terreros y Pando: «Nación: nombre colectivo que significa algún pueblo grande, reino, estado, etc., sujeto a un mismo príncipe o gobierno» ". Pero, ¿cuándo ese país o ese cuerpo social -Espańa- nace a la vida historiable?, ¿con los primeros pobladores de la península?, ¿con su unidad política?, y en tal caso, ¿con qué unidad? La que alcanzó con la Hispania romana se destruyó con la caída del Imperio y sólo dificultosamente volvió a lograrse, en un orden enteramente distinto, con los visigodos. Pero a su vez, la España visigótica quedó rota con la invasión islámica y sólo se reanuda, desde nuevas bases, con la obra unificadora de los Reyes Católicos. Pero esa obra unificadora tampoco va a dejar una monarquía de límites invariables, porque a los vastos territorios de América y las islas se van a ir sumando las sucesivas conquistas en diferentes ámbitos europeos (Italia, Países Bajos, etc.)...En fin, los propios títulos de la monarquía hacían evidente que todavía en el siglo XVIII, a pesar del proceso centralizador de los Borbones y del inequívoco acrisolamiento del sentido moderno de nación como conciencia colectiva de vida política en común ${ }^{10}$, España continuaba siendo de algún modo una nación de naciones. ¿Cómo

9. Diccionario castellano con las voces de ciencias y artes y sus correspondientes en las tres lenguas francesa, latina e italiana, Madrid, Viuda de Ibarra, 1786-1793. Apud Javier Fernández Sebastián, «España, monarquía y nación. Cuatro concepciones de la comunidad política española entre el Antiguo Régimen y la Revolución liberal», Studia Histórica Contemporánea, XII (1994), pp. 45-74.

10. Sobre esta idea, y la importancia decisiva que tiene el XVIII en la formación del vínculo comunitario de nación, vid. José Antonio Maravall, «El sentimiento de nación en el siglo XVIII: la obra de Forner», La Torre (Universidad de Puerto Rico), XV, julio-septiembre, 1967, pp. 25-56. Reed. en Estudios de la historia del pensamiento español (siglo XVIII), ed. C Iglesias, Madrid, Biblioteca Mondadori, 1991, pp. 42-60; el artículo de J. Fernández Sebastián citado en la nota anterior; Gonzalo Anes, «La idea de España en el Siglo de las Luces», en España. Reflexiones sobre el ser de España, Madrid, Real Academia de la Historia, 1998, pp. 223242; José Andrés-Gallego, «Los tres conceptos de nación en el mundo hispano», en Nación y constitución: de la Ilustración al Liberalismo, ed. Cinta Canterla, Sevilla, Junta de AndalucíaUniversidad Pablo de Olavide-Sociedad Española de Estudios del Siglo XVIII, 2006, pp. 123-146; Santos M. Coronas, «Nación y Constitución en el pensamiento jurídico español del siglo XVIII», ibid., pp. 147-165. Una visión general de la proyección de este nuevo concepto en la teoría y praxis historiográfica puede verse en el capítulo de Enrique García Hernán, "Construcción de las historias de España en los siglos XVII y XVIII», del volumen La construcción de las historias de España, coord. Ricardo García Cárcel, Madrid, Fundación Carolina-Centro de Estudios Hispánicos e Iberoamericanos-Marcial Pons Historia, 2004, pp. 127-193. 
proceder, pues, a la hora de encarar la actividad literaria de esa comunidad múltiple -cruce de pueblos, etnias, religiones y culturas- del devenir español?

La otra vía era apelar a criterios lingüísticos, toda vez que la literatura siempre se expresa a través de una lengua determinada. Pero también en este caso había problemas metodológicos, porque, ¿cuál es la lengua española?, ¿el castellano? Ciertamente sí, ya que es la que por razones históricas acabó por ser la lengua española propiamente dicha. Pero, ¿era legítimo prescindir de las demás lenguas vulgares? Máxime en la Edad Media, cuando la fragmentación política y étnico-religiosa hace de España un mosaico de lenguas romances y no romances -con el importantísimo ańadido del latín, la lengua de la Iglesia y de la cultura- que están lejos de ser impermeables a influencias mutuas. En los tiempos sucesivos el problema será menos acuciante por la decidida expansión y consolidación como lengua nacional del castellano; pero de algún modo continúa estando presente, porque el latín sigue generando literatura y también lo hacen, aunque en medida mucho más limitada, las otras lenguas peninsulares.

Como podremos comprobar en las páginas que siguen -centradas en el análisis de cinco de las más notables y significativas historias literarias del siglo XVIII-, ambas vías, con variedad de propuestas y soluciones, están vigentes en la práctica historiográfica. Aunque, ciertamente, para tener una idea cabal del asunto habría que extender la mirada a todo el mapa de recorridos históricos de la época, creo que la revisión de ese puñado de textos nos permitirá reconocer tanto esa variedad de criterios, como la de los parnasos nacionales que fueron su resultado.

\section{Fr. Martin Sarmiento}

Para el fundador de la historiografía literaria moderna, la cuestión parece estar del todo clara. Cuando el 21 de abril de 1745 remite al cardenal Valenti Gonzaga el manuscrito de cincuenta pliegos que recogen los resultados de su trabajo, resume su contenido en una frase: "contienen casi todo lo que he podido coordinar sobre la Poesía en Espańa» (p. XXI). El cardenal, según declara poco después, le había preguntado "sobre la poesía y poetas españoles», y de resultas de ello habían nacido sus Memorias para la historia de la poesía y poetas españoles; una obra con la que no pretende construir una historia literaria cabal y sistemática -para lo que es consciente habría sido necesario disponer de informaciones y lecturas mucho más amplias y precisas-, sino más bien reunir en forma de "apuntamientos» todos los materiales y noticias que ha conseguido allegar para forjar el itinerario 
temporal de la literatura hasta los Reyes Católicos, que es el término final que impone a su recorrido. $\mathrm{Y}$ en efecto, a ese designio acumulativo y al hecho de no ir destinada a la publicación -saldría póstumamente en 1775se debe imputar el trazado un tanto disperso de que adolece la obra, como ya advirtió Sempere y Guarinos ${ }^{11}$.

Sea como fuere, el criterio que preside su actividad historiadora a la hora de abordar la poesía española es el histórico, no el lingüístico, como se echa de ver en los epígrafes que van enmarcando sus consideraciones: "Antigüedad de la poesía en España», "Callaicos o gallegos», "Poesía latina en España», "Poetas españoles del siglo XII», etc. Aunque en ningún momento se detenga a precisar la naturaleza de su concepto de España, resulta claro que su enfoque nacional se sostiene sobre la premisa de un país, una entidad territorial, existente desde el origen mismo de la historia:

Es notorio que mientras no haya Historias particulares de la Poesía de cada Nación jamás se podrá componer Historia general completa. No hay Nación alguna en todo el Orbe, que de presente o en lo antiguo, o juntamente desde su origen hasta el presente no haya ejercitado la Poesía a su modo, y según su idioma (p. 8).

España, la nación española, es el solar que, habitado sucesivamente por gentes de muy diversa procedencia y condición, ha ido alumbrando con el correr del tiempo una cultura y una poesía. Con independencia de su lengua o religión, todos, dice, han concurrido a formar la literatura española: «... para el asunto de que se va tratando de la Poesía en España, no es del caso que los españoles fuesen mahometanos, judíos, apóstatas, malos o buenos cristianos, como fuesen singulares en la Poesía rimada, en esta u en otra lengua» (pp. 81-82). Del mismo modo que hay una poesía griega, latina, hebrea, francesa o italiana, hay también una poesía española; y ésa es la que trata de rastrear espigando cuantas noticias pueden suministrarle las fuentes que maneja ${ }^{12}$ acerca de los «antiguos españoles»-cántabros, celtíberos, bastetanos, gaditanos, turdetanos, gallegos-, los que vinieron a asentarse después en el suelo peninsular (romanos, visigodos, árabes, hebreos), y los que luego integraron la comunidad de reinos medievales y escribieron «en vulgar Español»-en las distintas lenguas vulgares-, que son los que

11. Juan Sempere y Guarinos, Ensayo de una biblioteca de los mejores escritores del reinado de Carlos III, Madrid, Imprenta Real, V, 1789, p. 112.

12. Amén de numerosos trabajos de carácter histórico y filológico, tanto españoles como foráneos, de la Biblioteca Hispana de Nicolás Antonio y de las contribuciones conocidas sobre el tema (Argote de Molina, Viaje del Parnaso, etc.), cuenta, como es sabido, con el texto todavía inédito de la Carta prohemio de Santillana, base de una gran parte de sus noticias sobre la literatura medieval. 
constituyen la parte del león de sus Memorias; poetas castellanos desde luego, pero también «lemosinos», gallegos y portugueses, pues a todos ellos alcanzan sus indagaciones, si bien, cuando se trata de estos últimos (Don Dionís, el conde de Barcelos, Vasco Pérez de Camoes, Vasco de Lobeira...), marcando habitualmente, desde su actual conciencia histórica, esa condición nacional. Aunque es plenamente consciente de la matriz castellana del español y sean castellanas las más de las obras de que se ocupa, puesto a rescatar la herencia literaria de España en sus tiempos más oscuros, prefiere optar, hasta donde los materiales de que dispone se lo permiten ${ }^{13}$, por la mirada que mejor pueda devolver su imagen más completa y acabada.

Mientras que la narración que anuda en el más remoto pasado es una historia sin títulos y sin nombres, a partir de la dominación romana empieza a poblarse con referencias concretas. En la España romana, Sextillo Hena, Séneca, Columela, Marcial, Liciniano y el «insigne» Lucano, que es en el que más se detiene para vindicar su obra; tras la decadencia de Imperio, «el insigne español Prudencio», Juvenco, S. Dámaso, Latroniano, Dragoncio, Eugenio Toledano, Álvaro Cordubense; luego, los árabes y hebreos -de los que muy someramente trata en el capítulo de "Rimas orientales- ${ }^{14}$, y finalmente, los poetas o poemas en lengua vulgar: Cantar de Mio Cid, Fernán González, Poema de Alexandre (conocidos los tres únicamente por unos breves fragmentos), Berceo, Alfonso el Sabio, López de Ayala, etc., hasta llegar a los del siglo XV, en el que por la abundancia de nombres conocidos -más de doscientos-, decide proceder con una cierta selección, graduando la atención según el interés e importancia de los textos considerados:

Para este siglo décimo quinto en que entramos ya hay menos escasez de noticias ciertas, y es constante que sin salir de los dos Cancioneros impresos, Portugués y Castellano, se pueden colocar en este siglo más de doscientos Poetas Españoles. Ya se ve que eso sería prolijidad enfadosa, pues no es mi asunto componer Biblioteca poética. Por lo cual, usando de varias remisiones y citas, ya será mi particular estudio escoger lo más selecto entre lo mucho y disponerlo según el orden cronológico y según el orden de los más famosos poetas (p. 359).

13. Entre otras obras que lamenta no conocer (v. gr. las poesías del Arcipreste de Hita), están las canciones galaico-portuguesas de que tiene noticia a través del testimonio del Marqués de Santillana.

14. Para la poesía de los árabes y judíos españoles sólo dispone de las escasísimas noticias que ha podido leer en Aldrete y en los autores que menciona en dicho capítulo (Massieu, Formont, Herbelot, Fr. Francisco Gonzaga...). Recuérdese que aún no se habían publicado la Bibliotheca arábico-hispana (1760 y 1770) de Casiri ni la Biblioteca española (1781-1786) del hebraísta Rodríguez de Castro. 
Forja así el patrimonio canónico de los poetas del XV, aquellos que merecen destacarse y que no son otros que el «celebrado Juan de Mena», el marqués de Santillana, el «agudo» Jorge Manrique, autor de la famosa elegía Recuerde el alma dormida, Ausias March, "cuyas poesías han sido y son muy estimadas", Jaime Roig, y el anónimo autor de las Coplas de Mingo Revulgo.

Pero en las épocas precedentes, el benedictino no orienta su narración en la línea de la canonicidad. Erigido en fedatario de la actividad poética española antes que en crítico ( ni mi asunto es crítica de los Poetas, ni mis talentos son para este asunto», p. 185), su interés primario reside en la aportación de noticias que permitan reconstruir pieza a pieza y con la mayor precisión posible -aun cuando sólo tenga un conocimiento indirecto o fragmentario de los textos- el curso de la poesía nacional en sus tiempos más oscuros. Por ello, y tal vez por su confesada despreocupación por el arte de la palabra ${ }^{15}$, aunque se extiende ampliamente en la consideración de diferentes textos y autores (Berceo, Alfonso X, el Canciller Ayala, etc.), apenas desliza alguna que otra valoración estimativa, que no van más allá de las escuetos calificativos de los poetas del XV que acabo de mencionar y de la propuesta de desplazar de Mena a Berceo la consideración de «Ennio español» por su mayor antigüedad y estilo «más anticuado, más puro y más sencillo» (p. 268). El sumo interés que, a su juicio, tendría la publicación de buena parte de las obras que menciona estriba no tanto en sus valores artísticos, que, como digo, soslaya habitualmente, cuanto en su condición de piezas «clave» para el conocimiento de la lengua y costumbres antiguas.

Sea como fuere, gracias a su esfuerzo por reunir y coordinar cronológicamente las noticias sobre la actividad poética desarrollada en el territorio en que se irá forjando la comunidad nacional desde su más remoto pasado hasta los inicios de la edad moderna, queda constituido nuestro primer Parnaso histórico. Un Parnaso, importa precisar, que no se ciñe exclusivamente a la literatura medieval, pues al trazar la historia de la rima y metros castellanos -asunto al que presta notable atención como investigación indisociable de su trabajo-, o a propósito de otras cuestiones, introduce diversas referencias a poetas y escritores posteriores. Así, Garcilaso logró con sus versos «el común aplauso y mereció el renombre de Príncipe de los Poetas castellanos» (p. 214), Gregorio Silvestre, que nació en Lisboa y pasó con su padre a vivir a Castilla, «es muy celebrado por sus poesías castellanas» (p. 215), Quevedo y Góngora son «inimitables» en la poesía

15. Confesión que sagazmente matiza Rusell P. Sebod, «Marín Sarmiento y la doctrina neoclásica» [1977], El rapto de la mente. Poética y poesía dieciochescas, Barcelona, Anthropos, 1989, pp. 129-137. 
satírica, jocosa y burlesca (p. 162), Lope de Vega, poetizó con extraordinaria facilidad y felicidad (p. 184), etc. El Parnaso, en definitiva, que traduce su convencimiento de que «en cualquiera edad, en cualquiera lengua y en cualquier dominio, siempre los Espańoles han sido muy aficionados a la poesía, música, bailes y regocijos inocentes» (p. 238). Pero de esa experiencia colectiva, sobre la que tan denodadamente había levantado el primer sillar, todavía quedaba mucho por saber.

\section{Luis José Velázquez, marqués de Valdeflores,}

El planteamiento de Luis José Velázquez en sus Orígenes de la poesía castellana (Málaga, 1754), escrita, no se olvide, mucho antes de que se publicara la obra de Sarmiento, difiere no poco del benedictino. No sólo porque se muestra mucho más atento al orden y estructuración de su relato -que avanza hasta el momento presente- y ensaya una periodización interpretativa, sino porque decide focalizar su mirada en la literatura escrita en castellano, tal como refleja su título. Consciente, sin embargo, de que ello implicaba renunciar al conjunto del caudal poético anterior así como al de otras lenguas que también desarrollaron una literatura propia y pudieron influir en el castellano, echa mano de un ingenioso dispositivo hermenéutico para hacerlas comparecer, integradoramente, en el relato de la literatura nacional, que no es otro que dedicar un largo capítulo a las que llama "Fuentes de que se deriva la poesía castellana», constituidas por "la poesía de los Espańoles primitivos, la latina, la arábiga, la provenzal o lemosina, la gallega, la portuguesa, y si acaso puede serlo, la poesía vazcuense» (sic) ${ }^{16}$; siete ámbitos poéticos forjados en el empleo literario de las otras lenguas del territorio peninsular y signados cada uno de ellos por un carácter o índole particular, que al «dimanar» a la literatura en castellano determina «en parte la falta de unidad de carácter que se observa en la poesía castellana, que imitó algo de unas y de otras» (p. 29). Aunque explícitamente no entre a valorar la pertenencia o no de esos ámbitos poéticos a la literatura nacional, a través de sus calificativos y del afán por llenarlos de contenido recurriendo a diversas fuentes impresas y manuscritas, se percibe el empeńo por recuperar un pasado común más allá de los avatares políticos de la historia. «Españoles» fueron esos pueblos primitivos -turdetanos, gallegos- de que habla en primer lugar, los que luego escribieron en latín tanto bajo la dominación romana como después (Julio Higinio, Sextillo Hena, los dos Sénecas, Lucano, Marcial, Juvenco, Prudencio, Draconcio, Orencio, San Ildefonso, Juliano, Álvaro

16. Cito por la segunda edición: Luis Josef Velázquez, Orígenes de la poesía castellana, Málaga, Herederos de D. Francisco Martínez de Aguilar, 1797, p. 7. 
Cordobés, San Eulogio, etc.), los que lo hicieron en árabe -de los que avanza algunas noticias procedentes de la Biblioteca de Casiri, que está, dice, a punto de salir: hombres y mujeres, como la sevillana María Alphaisuli, «la Safo de la poesía árabe»-, y los «provenzales-españoles» alineados al arte de la gaya ciencia (D. Alonso I de Aragón, Mosén Jordi, Jaime Febrer, Raimundo Montaner, Ausias March, etc.). Y también se entiende que lo han sido los que escriben en gallego (Alfonso X, Macías) y los que en fechas más tardías han poetizado en "vazcuense», como Fr. Juan de Aramburu, Bernardo de Gazteluzar o Juan de Echeverri. La poesía portuguesa, en cambio, aunque por razones de parentesco también se incluye en ese cuadro de las literaturas hispánicas, aparece enfocada, de acuerdo con la conciencia nacional contemporánea, como un ámbito poético distinto del propiamente español. Y es en él donde quedan integrados tanto los poetas que florecen en la literatura medieval (Gonzalo Hermíguez, Don Dionís, etc.), como en fechas más tardías (Gil Vicente, Saa de Miranda, Camoens, Francisco Roiz Lobo, el conde de Ericeyra, etc.). Ciertamente, a esa visión de las literaturas hispánicas como fuentes nutricias del castellano se podrían hacer serios reparos; pero no cabe duda de que introducir tal capítulo y apelar a ese modelo expositivo era una forma de resolver el conflicto que para él tuvo que suponer ensamblar, en un conjunto ordenado y coherente, el desarrollo de la literatura escrita en la que habría de ser la lengua nacional-que es la que por ello vertebra el proyecto de su indagación histórica (aunque sobre ello no haga ninguna declaración) - y el de las que fraguaron también otras lenguas que no por eso fueron menos españolas. Cuestión distinta es, como digo, que ese modelo fuera o no el más acertado.

A diferencia también de Sarmiento, su construcción histórica está gobernada por una clara intencionalidad estética y polémica. Porque además de situar a los autores en el curso temporal de la literatura, su pretensión es captar e interpretar el dinamismo interno del arte literario según criterios de apreciación artística -alteraciones, avances y retrocesos- para así marcar las sucesivas «edades» de la poesía castellana desde su origen hasta el presente (p. 7) y valorar a los escritores con arreglo a sus convicciones teóricoreformistas. Ofrecer, en suma, un parnaso crítico guiando a los lectores para que sepan graduar el mérito intrínseco de los textos y puedan secundar la renovación clasicista promovida por sus amigos Luzán, Nasarre y Montiano y Luyando, tres voces que devotamente suma a la suya para desarrollar ese doble programa de historia y pedagogía. Por eso el juicio estético acompaña con mucha más frecuencia que Sarmiento sus referencias a obras y autores. Sobre todo los de los dos últimos siglos, a los que por la influencia que han ejercido, o pueden ejercer, en la poesía actual dedica un mayor tratamiento 
crítico. Prueba evidente de esa preocupación por acertar a calibrar el verdadero mérito de los autores es la correspondencia que mantiene con Montiano durante el tiempo de redacción de la obra ${ }^{17}$. Así, por la autoridad que le otorga en materia teatral, le pide: "Quisiera que V. me dixese qué comedias podré alabar en particular y porqué; y asimismo cuáles son los autores que por lo general son buenos en este asumpto y qué juicio podré hacer de la comedia traducida por nuestro Luzán» ${ }^{18}$. Y es que, para él, tan importante como la información histórica es la evaluación de la actividad poética a la luz de los principios de la creación artística («arte»).

Para hacer realidad ese proyecto, sistematiza la exposición en torno a dos ejes; por un lado, introduce el modelo orgánico de evolución artística proyectando a la literatura las cuatro edades del ciclo vital de un organismo vivo -infancia, juventud, madurez y vejez- y así mostrar sus fases de nacimiento, crecimiento, apogeo y decadencia; un modelo utilizado ya por Aristóteles para describir el proceso de la tragedia ${ }^{19}$ y que en el Renacimiento había recuperado Vasari para plasmar la evolución histórica de las artes:

La poesía castellana, según los progresos y alteraciones que ha tenido desde su origen hasta hoy, se puede dividir en cuatro edades. La primera será desde su principio hasta el tiempo del Rey D. Juan el II. La segunda, desde D. Juan el II hasta el emperador Carlos V. La tercera desde el tiempo de Carlos V hasta el de Felipe IV. Y la cuarta desde entonces hasta el presente. En la primera edad se puede contemplar la poesía castellana como en su niñez; en la segunda como en su juventud; en la tercera como en su virilidad, y en la cuarta como en su vejez (p. 33).

Según este esquema, esbozado ya por Mayáns y Luzán, cada una de estas fases o secuencias presenta un perfil característico a tenor de los cambios de gusto que se han ido produciendo. Hasta el siglo XIV, la literatura castellana vive un tiempo de iniciación escasamente propicio para lograr frutos granados ( «los poetas de este tiempo, que carecían de invención y de numen, apenas acertaban a ser buenos rimadores», p. 42); en el siglo XV se advierte ya una sensible mejoría («en esta segunda edad comenzó la poesía castellana a mudar de semblante, perdiendo mucho de su primitiva rudeza»,

17. Cfr. Philip Deacon, «La historia interna de los Orígenes de la poesía castellana de Luis Joseph Velázquez», Boletín del Centro de Estudios del Siglo XVIII (Oviedo), no 6 (1978), pp. 65- 82 .

18. Ibid., pp. 68-69.

19. Cfr. René Wellek, "El concepto de evolución en la historia literaria», en Historia literaria. Problemas y conceptos, selección de Sergio Beser, Barcelona, Editorial Laia, 1983, pp. 23-35. 
p. 51); en el XVI, con el restablecimiento de las letras y el magisterio de los clásicos, alcanza su plenitud, razón por la cual le otorga el elogioso marbete de Siglo de Oro, tomando una noción, a la vez temporal y valorativa, que ya estaba en uso para calificar los brillantes periodos de Augusto y León $\mathrm{X}^{20}$ («esta tercera edad fue el siglo de oro de la poesía castellana, siglo en que no podía dexar de florecer la buena poesía al paso que habían llegado a su aumento las demás buenas letras. Los medios sólidos de que la nación se había valido para alcanzar este buen gusto no podía dexar de producir tan ventajosas consecuencias. Se leían, se imitaban y se traducían los mejores originales de los griegos y latinos, y los grandes maestros del arte, Aristóteles y Horacio, lo eran asimismo de toda la nación», pp. 58-59); en el XVII, sin embargo, se produce una notable decadencia a causa de la artificiosidad e "hinchazón enfermiza» de que abusan sus poetas más cualificados; y ya en el XVIII se emprende el camino de la recuperación.

Pero no contento con esta única vía expositiva, complementa su visión de la literatura española con un recorrido histórico-crítico por sus principales modalidades genéricas (cap. III. Principio y progreso de la poesía castellana en cada una de sus principales especies en particular): lo que le permite ampliar y matizar las noticias y apreciaciones desarrolladas en el capítulo anterior. Bien es verdad que, de acuerdo con su percepción de la poesía («imitación de la naturaleza hecha en verso»), excluyendo de la literariedad la novela y las demás modalidades de prosa literaria.

Reuniendo las referencias a la extensa nómina de autores que va haciendo comparecer a través de esa doble vía se hace patente la escala y gradación de sus valores literarios.

En la primera época -la más avara en apreciaciones críticas -, de los autores que menciona (Berceo, Alfonso X, don Juan Manuel, Ayala, el Arcipreste de Hita) el que emerge con mayor estatura poética es el último, al que aunque confiesa no conocer sino a través de un amplio extracto que le ha comunicado "una persona muy docta», entiende que merece la pena reseñarlo en extenso "por ser de una idea singular e ingeniosa» (p. 35), y que sea reputado, por su sátira a las malas costumbres de su tiempo, «como el

20. Para un análisis más detenido acerca de la génesis y desarrollo de esta noción, remito a los trabajos de Nicolás Marín («Meditación del Siglo de Oro, Granada, 1982), José Manuel Rozas («Siglo de Oro: historia de un concepto, la acuñación del término», en Estudios sobre el Siglo de Oro. Homenaje al profesor Francisco Ynduráin, Madrid, Editora Nacional, 1984, pp. 413-428), Frank Baasner («Una época controvertida. La polémica sobre el Siglo de Oro en la historiografía española de los siglos XVIII y XIX», Revista de Literatura, no 119, 1998, pp. 58-78) y Alberto Blecua («El concepto de Siglo de Oro», en Historia literaria / Historia de la literatura, ed. Leonardo Romero Tobar, Zaragoza, Prensas Universitarias de Zaragoza, 2004, pp.115-160. 
Petronio de la poesía castellana, pues en la invención acaso no se le aventaja el poeta latino» (p. 41).

En la segunda, son ya varios los poetas que merecen una calificación claramente positiva: Mena, «el más famoso de este siglo y del que se puede decir que dio un nuevo semblante a la poesía castellana» (p. 49), Jorge Manrique «que escribió las coplas castellanas con más pureza y facilidad que otro de su siglo» (p. 49), Garci Sánchez de Badajoz, «igual [que éste] en la pureza del estilo» (p. 49), Juan del Encina, «el primero en quien la buena poesía daba ya muestras de querer manifestar su vigor» (p. 50) y quien dio principio, junto con D. Enrique de Villena, a la imitación poética, «haciendo hablar en castellano al mejor de los poetas latinos» (p. 51), y el marqués de Santillana, que sacó a la poesía «de las mantillas de sus coplas haciéndola hablar en el ritmo de las provenzales y de los italianos» (p. 51). De La Celestina, piensa que aunque tiene caracteres propios y descripciones muy vivas y naturales sería de muy mal ejemplo si llegara a representarse (p. 83).

En la tercera época, la más excelsa de la literatura española gracias al renacimiento del gusto auspiciado por el influjo italiano y la imitación de los clásicos, la relación se amplía considerablemente. Los tres que figuran en cabeza son Garcilaso, «que con razón es tenido por el príncipe de la poesía castellana» (p. 53), Fray Luis de León, «a quien no sólo nuestra lengua, sino también nuestra poesía debe en gran parte la altura a que llegó en esta edad», "un genio superior cultivado con el conocimiento de las lenguas sabias» que le hizo caminar por las sendas más difíciles del arte imitando y aun traduciendo a los mejores originales de las naciones cultas (p. 56), y Villegas, de extraordinaria facilidad para el ritmo y uen cuyas poesías se admira el espíritu de Horacio, la suavidad y gracias de Anacreonte, la galantería de Tibulo, la urbanidad de Propercio y el genio para imitar la naturaleza de Teócrito» (p. 56). Pero también le merecen gran estima Pedro de Padilla, «uno de los mejores poetas de este siglo» (p. 54), el portugués Saa de Miranda, cuyas poesías castellanas deben considerarse «entre las mejores de aquel tiempo» (p. 54), Alonso de Ercilla, por la madurez a que condujo la epopeya, y Cristóbal de Castillejo, admirable por su particular "genio" satírico y la inimitable gracia y donaire de sus coplas castellanas (p. 5-55, 111). Nada dice en cambio de San Juan de la Cruz. En el terreno teatral, destaca a Lope de Rueda, el primero que «empezó en España a restaurar el teatro» (p. 86), Cristóbal de Castillejo, "que compuso algunas comedias excelentes, aunque algo libres» (p. 88), Torres Naharro, merecedor del elogio que hace a su estilo el autor del Diálogo de la lengua (p. 88), Jerónimo Bermúdez, cuyos limados versos «se acercan a la elegancia y armonía de los griegos y latinos» (p. 55), 
Juan de la Cueva, a quien debe contarse entre los buenos de ese tiempo «y por uno de los que adelantaron la poesía dramática después de Naharro» (p. 55) y Cervantes, quien «ayudado de su peregrina y vasta invención compuso muchas comedias que, como él mismo asegura, podrían servir de modelos» (se refiere a las de su primera época, no a las publicadas en 1615, que en coincidencia con la peregrina interpretación de Nasarre en la Disertación que acompaña a su edición de las Comedias y entremeses, cree que las escribió desarregladas para ridiculizar el arte de Lope). Siguiendo igualmente el panorama crítico de Nasarre, atribuye a Lope y a Virués haber sido los que empezaron a "corromper» el teatro; una corrupción que fue tomando cada día más cuerpo y que culminó con Calderón. En cuanto a la tragedia, sus noticias y valoraciones siguen muy de cerca las formuladas por Montiano en sus dos Discursos sobre el tema. Queda claro, de todos modos, que para el autor de los Orígenes no todo fue oro en ese siglo de oro, pues hubo también mucha poesía mediocre por falta de ingenio e invención, dureza de estilo, u otros defectos artísticos.

En la cuarta época las menciones positivas decrecen visiblemente. A su juicio, el comienzo del declive empieza a notarse ya en varios autores que aunque no dejan de tener algunas obras buenas e incluso excelentes, traslucen en otras "el mal gusto que empezaba ya a reinar en la poesía castellana» (p. 57). Del conde de Rebolledo lo mejor es La selva sagrada, La constancia victoriosa, Los trenos y el Idilio sacro; de Vicente Espinel, algunas canciones y en especial su traducción del Arte poética de Horacio; de Luis de Ulloa, algunos sonetos, canciones y sátiras; de Pedro de Espinosa, la Fábula del Genil; de Jáuregui, la traducción de la Aminta de Tasso; de Cristóbal de Mesa, las versiones de la fábula de Narciso de Ovidio y del Beatus ille de Horacio; y de Quevedo, entre «lo mucho y bueno» que tiene, las poesías que él cree "publicó con el nombre supuesto del Bachiller Francisco de Torre», algunas sátiras y canciones y la traducción de Epicteto y Focílides. En otro momento dirá de sus idilios que «no son inferiores a los de Moscho, Bión y Teócrito» (p. 110).

El tiempo que va a seguir será ya de franca decadencia a causa del «desorden y mal gusto» que introdujeron Marino y otros italianos (p. 59) y de la perniciosa influencia de la Agudeza y arte de ingenio de Gracián. Ese mal gusto dio origen a lo que él llama las tres «sectas» corruptoras de nuestra poesía: la de los dramaturgos irregulares que ignoraron o despreciaron las reglas de los antiguos, la de «los conceptistas», que redujeron todo el primor del estilo a conceptos, hipérboles y agudezas, y la de los "cultos», iniciada por Góngora y caracterizada por el empleo de cultismos y neologismos, una erudición afectada y "la dicción pomposa y llena de estrépito» (pp. 60-61). 
Pero convencido del avance que se ha producido ya en la percepción del hecho literario, considera que no hace falta entrar a justificar con más detalle la exclusión de los promotores de esa «revolución» del grupo más selecto del parnaso espańol:

No creo necesario detenerme aquí a examinar si los principales xefes de esta revolución son o no dignos de una más individual censura y menos si sus escritos los hacen o no acreedores a ser colocados en el parnaso español entre los buenos poetas castellanos, porque sería ofender en cierto modo a un siglo tan instruido como el en que vivimos (sic) sospechar que aún hoy era necesario este desengaño y sólo se lograría enfadar a los que en estos asuntos tienen voto con repetirles de nuevo una disputa que sólo hubiera sido tolerable en un siglo como el pasado (pp. 61-62).

No faltan, con todo, diversas menciones muy positivas acerca de algunos poetas de este tiempo. En la poesía jocosa y «ridícula», considera sobresalientes la Gatomaquia y demás poesías burlescas que Lope escribió bajo el nombre de Tomé de Burguillos, así como La mosquea de Villaviciosa; en la epigramática, más que a Rey de Artieda estima a Lope, Ulloa y los Argensola, "que guardan rigurosamente todas las leyes que pide esta casta de composición» (113); en la elegía, a Lope («hizo algunas harto buenas», p. 110), Quevedo y el conde de Rebolledo; y en la égloga, a Lope igualmente («merecen [sus églogas] más estimación que la mayor parte de sus demás obras», p. 108).

Llegado ya a la época contemporánea, en que «las letras han tomado entre nosotros otro nuevo semblante» y la poesía "va volviendo a recobrar su antigua majestad y decoro", pese a los defectos y puerilidades con que han querido "afearla» algunos malos poetas (p. 63), los autores que destaca son cuatro muy próximos a él: Luzán («uno de los mejores poetas que tiene hoy la nación»), Montiano -tanto por sus églogas aún inéditas como por las dos tragedias recientemente publicadas, Virginia y Ataulfo-, el conde de Torrepalma, del que como muestra de su ingenio sólo menciona el Discurso sobre la comedia, y Porcel, particularmente por las églogas venatorias de su también inédito Adonis «en que hay pedazos excelentes y tan buenos como los mejores de Garcilaso» (p. 65).

Aunque es forzoso reconocer que hay todavía muchas lagunas y silencios en el cuadro del Parnaso español que dibujan los Orígenes de la poesía castellana, no cabe duda de que en este primer encuentro consciente entre la estética y la historia, Velázquez no sólo fija los perfiles más significativos del canon de la literatura española; logra igualmente, como celebra su amigo Montiano en la censura de la obra-impresa al frente-, unir muchos materiales curiosos 
"y formar con ellos una idea de lo que ha sido y es nuestra poesía desde su cuna ${ }^{21}$. De la castellana desde luego, como era su intención, pero también, gracias a su visión integradora, de las otras Españas.

\section{Los hermanos Rodríguez Mohedano}

Doce años después de publicada la obra de de Velázquez, aparece en escena el primer tomo de la Historia literaria de España desde su primera población hasta nuestros días (1766) de los hermanos franciscanos Pedro y Rafael Rodríguez Mohedano, primera entrega de un ambicioso proyecto que irá continuándose a lo largo de quince años hasta finalizar, con el undécimo tomo, en 1791. Dedicada a Carlos III, su plan era trazar la historia general de la cultura («literatura») española desde el principio hasta la actualidad: un colosal objetivo de inequívoco sesgo nacionalista, alentado tanto por el afán de mostrar por primera vez el desarrollo diacrónico de las ciencias y artes en Espańa -ya planteado por la Academia de la Historia -, como por el de reivindicar su mérito ante las naciones extranjeras:

Deseamos hacer ver el distinguido mérito de muchos Héroes de nuestra literatura en todos sus géneros y mostrar cuántos Colones de ella han hecho expediciones gloriosas y felices descubrimientos en el orbe literario. Como verdaderos patricios nos dolemos de ver olvidada nuestra España, o de intento omitida por los extranjeros, en las enumeraciones que hacen de las naciones cultas y literatas ${ }^{22}$.

El extenso prólogo de la obra da cuenta detallada de los muchos problemas metodológicos que los autores se plantearon y trataron de resolver para la adecuada consecución del proyecto. Obviamente, uno era la determinación de su área de estudio. Según declaran, su primitiva idea era iniciar la historia literaria «de España» en el siglo de Augusto, la época de nuestros primeros escritores o cuando menos de aquéllos cuya memoria u obras han llegado hasta nosotros, pues les parecía «natural» que una obra dedicada a ilustrar la literatura de la nación comenzase por aquel tiempo en que, después de siglos bárbaros y luchas continuas, tuvo ocasión de aplicarse a las letras bajo el

21. Ibid., p. 5.

22. Historia literaria de España desde su primera población a nuestros días, origen, progresos, decadencia y restauración de la Literatura española; en los tiempos primitivos de los Phenicios, de los Cartagineses, de los Romanos, de los Godos, de los Árabes y de los reyes católicos, con las vidas de los hombres sabios de esta Nación; juicios criticos de sus obras; extractos y apologías de algunas de ellas: disertaciones históricas y críticas sobre varios puntos dudosos para desengaño e instrucción de la juventud española, por los PP. F. Pedro Rodríguez Mohedano y F. Rodríguez Mohedano, Madrid, imp. de Antonio Pérez de Soto, 1766, p. IV. 
pacífico gobierno de una nación culta. Entendían que todo lo anterior, lleno de fábulas e informaciones confusas y que daban razón más de barbarie que de cultura, había que dejarlo al margen ya que les impediría «poder tomar las cosas desde su origen». Tal como había hecho Nicolás Antonio en su Biblioteca Hispana. Pero comprendieron después que no debían proceder así, pues más allá de aquellas noticias inciertas había otras que permitían reconocer muchos signos de cultura (poesía incluida) en los tiempos anteriores y que por lo mismo era menester «retroceder desde el siglo de Augusto hasta la venida de los cartagineses, griegos y fenicios, y por el consiguiente, tomando las cosas desde su origen, buscar a nuestra historia un principio más alto y de más remota antigüedad» (pp. XCIV-XCV). Y en efecto, de acuerdo con ese nuevo plan, diseñan su historia llevándola hasta sus más «remotas antigüedades» confiando ilusionados en contribuir así a la «utilidad y gloria de nuestra Nación». Yendo más allá que Nicolás Antonio, proyectan dividirla en dos grandes partes, una para el «Estado antiguo» - desde los orígenes hasta mediados del XV-y la segunda, "el estado moderno», desde entonces hasta la actualidad. Un proyecto que sólo en muy pequeña medida habrían de llevar a cabo, pues, como es sabido, su desaforada erudición, poblada de conjeturas y digresiones de todo tipo, hará que la obra se trunque en el siglo I de nuestra era con la obra de Lucano.

Sobre lo que desde luego no albergan ninguna duda es la propia entidad de la nación española, por más que reconozcan -al tratar de los nombres de España- la ausencia de una verdadera comunidad política en sus tiempos más antiguos $^{23}$. Así, tras ofrecer una somera relación de los hitos fundamentales de su historia, escriben:

Tales son los diferentes estados en que la historia literaria debe representar la literatura de nuestra Nación; diferencia que no sólo conduce para la variedad amena y agradable de la historia, sino que en todos tiempos nos descubre el carácter de una Nación ingeniosa, con las mejores disposiciones naturales para el adelantamiento de las ciencias, y que a pesar de la diversidad de los tiempos, situaciones, y de los mayores estorbos por la sujeción a los extranjeros, por la dominación de los bárbaros, por las continuas guerras de que casi siempre fue teatro, nunca se desmintió a sí misma ni se obscureció la superioridad de sus talentos entre las mayores infelicidades y las más

23. «Algunos nombres tendría España antes que los fenicios y las demás naciones extranjeras vinieran a ella [...] Pero de ningún modo creemos que tuviera un nombre general toda la Península. Para esto hubiera sido preciso que sus pueblos tuvieran alguna unión entre sí y formaran un cuerpo político con algún género de gobierno universal a toda la nación» (I, p. 199). 
espesas tinieblas. Reunir tan grandes y diversos objetos, poner en un solo punto de vista la literatura de España en toda su extensión de tiempos y dominios de suerte que forme un solo cuerpo de historia, éste es todo el empeño de nuestro trabajo (p. LXXVIII).

Pero como no se les oculta la verdadera realidad, supraterritorial, de España, creen que razonablemente habría que extender el campo de consideración a los ámbitos que de algún modo han formado parte, o forman parte, de la comunidad nacional, como son los territorios europeos y la América española, sobre cuya cultura se proponen tratar ampliamente. No obstante, para evitar dilatar y hacer más confuso el panorama ven oportuno limitarse, en Europa, a los confines de la Península, aunque sin olvidar Portugal, especialmente en los tiempos en que estuvo "sujeta a nuestra dominación»:

Y aunque pudiéramos sin violencia ampliar el asunto extendiendo nuestra historia literaria a todos los países que han sido en algún tiempo de dominación española, como la Galia narbonense, gran parte de la Italia, alguna del África y del Asia, sobre todo el reino de Nápoles y Sicilia, los Países Bajos, la isla de Cerdeña, etc., mas no queremos dar extensión demasiada a un asunto vasto por su naturaleza y que pudiese embarazarnos con la misma multitud de especies, poniendo confusión y turbando el orden y claridad tan necesaria en la Historia. Así en la Europa nos reduciremos casi a nuestra Península, en la cual encontraremos suficiente espacio y materia abundante para una obra tan dilatada. Y aun dentro de ella no intentamos incluir de propósito al reino de Portugal, sin embargo de que no es inferior al resto de Espańa y que por tantos títulos nos interesan como muy proprias sus glorias literarias. Pero dejamos a la sabia nación lusitana el cuidado de ilustrar esta parte de su historia [...] como a quien más directamente pertenece [...]. Mas no por eso la miraremos como del todo extrańa; no la olvidaremos en los tiempos antiguos, y aún en los modernos, especialmente cuando estuvo sujeta a nuestra dominación [...]. Por lo que toca a la América, desde luego la incluimos en el plan de nuestra Historia Literaria, en atención a que no obstante su distancia no podemos mirar como extraños, ni dejar de apreciar como grandes los progresos de la literatura con que nos ha enriquecido una región no menos fecunda en ingenios que en minas (pp. LXXIX-LXXX).

Ese proyecto, sin embargo, tan ambicioso como bien planteado, jamás llegaría a hacerse realidad, ya que, como he dicho, no pudieron llevar su obra más allá del siglo I. Por eso, su Parnaso español quedó reducido a las escasas e imprecisas noticias que, entreveradas en el conjunto del desarrollo cultural, logran reunir sobre la poesía de los primitivos pueblos que habitaron la Península hasta el comienzo de la Era Hispana (tomos I a IV) y luego, las 
de la Hispania romana desde la época de Augusto en adelante, que es donde comparecen ya nombres y textos concretos, como son los de Cayo Julio Higino, Silio Itálico, los dos Séneca, Marcial o Lucano, esas grandes figuras cuyas obras más relevantes se complacen en resaltar, amén de defender de las críticas negativas que se han vertido contra ellos ${ }^{24}$. De todas formas, aunque no lleguen a entrar en la literatura moderna, podemos saber hacia dónde apuntan sus preferencias a través de algunas alusiones que dejan caer más o menos ocasionalmente. Así, a propósito del carácter español, escriben: «los Camoens, los Garcilasos, los Boscanes, los Padillas, los Esquilaches y los Argensolas, a quienes se les podía llamar delicias del orbe literario...» (I, p. 19). O replicando a la acusación formulada por Tiraboschi y Bettinelli de que los españoles corrompieron la literatura italiana en los tiempos antiguos y modernos: «Los italianos, así en aquellos siglos como en el pasado, tenían muy corrompido el gusto cuando les agradaron tanto los defectos de los oradores y poetas espańoles. Los excelentes oradores y poetas siempre son raros en todos los países. Grecia tuvo un Demóstenes y un Homero, Roma un Cicerón y un Virgilio. Italia un Tasso, España un Garcilaso, Portugal un Camoens [...] Lejos de haber corrompido los españoles la moderna elocuencia y poesía italiana, en el siglo XVI produjo España grandes oradores y poetas, que pudieron ser modelo del buen gusto» (V, p. 246). También para ellos, está claro, el XVI es el gran siglo de la literatura española.

\section{Francisco Javier Lampillas}

Cuando los Mohedano llevaban ya publicados los primeros tomos de su obra, empieza a salir en Génova una nueva contribución para el conocimiento histórico de la cultura espańola de carácter mucho más acusadamente apologético: el Saggio storico-apologetico della letteratura spagnuola (17781781) del jesuita Francisco Javier Lampillas, inmediatamente traducida al español por la notable ilustrada aragonesa Josefa Amar y Borbón (1782-1786). Como él mismo se encarga de precisar tanto en el prólogo como el cuerpo de la obra, su propósito no era formar una «biblioteca» de escritores ni construir una historia literaria completa de España, sino replicar, mediante un escrito pretendidamente no exhaustivo ("saggio»), a quienes ofuscados por prejuicios nacionalistas han menospreciado el valor de la cultura patria y han acusado a nuestra nación de haber sido la cuna del mal gusto (sutileza, afectación,

24. Defensa que ya anticipan en el tomo VII (1781), íntegramente formado por una Disertación apologética sobre la corrupción de la literatura y elocuencia romana; su época y causas: defensa de los españoles, especialmente de Marco Séneca y la familia Annea, para responder a las acusaciones de los italianos Bettinelli y Tiraboschi y otros críticos europeos. 
excesos imaginativos...) y de influir negativamente -tanto en la antigüedad como en la edad moderna- en la literatura italiana. Fundamentalmente, los historiadores de la poesía y cultura italianas Bettinelli, Tiraboschi, NapoliSignorelli y Quadrio ${ }^{25}$.

Espoleado por este propósito apologético, y entendiendo por literatura no su sentido restringido de «bellas letras», ya por entonces en curso, sino el general de ciencias, artes y erudición ${ }^{26}$, proyecta su mirada hacia todo el conjunto de la cultura -si bien privilegiando la filosofía, teología, la ciencia, el derecho y la expresión propiamente artística (oratoria, poesía y teatro)-, y modela el discurso en una larga constelación de disertaciones-respuesta a las principales incriminaciones de los italianos, de cuyo sentido dan fe los expresivos epígrafes que los encuadran (v. gr. Los españoles tuvieron particular influjo en la primera cultura de la lengua y poesía vulgar italiana, De la pretendida rusticidad de los antiguos versos españoles y de la parte que tuvieron los italianos en la perfección a que llegó la poesía española en el siglo XVI, etc.). Por eso, en efecto, no es una historia literaria en sentido estricto, sino más bien una suma de monografías intencionadamente polémicas, doctas y bien documentadas en general, pero no exentas, como ya hizo notar Menéndez Pelayo, de ciertas exageraciones y proposiciones aventuradas hijas del apasionamiento ${ }^{27}$.

Desde una percepción de España como un continuum existente desde un remoto pasado, ese conjunto de monografías lo clasifica en dos

25. Saverio Bettinelli, Del risorgimento d'Italia negli studi, nelle arti e nei costumi dopo il mille (1775), Girolamo Tiraboschi, Storia della letteratura italiana (1772-1782), Pietro Napoli-Signorelli, Storia critica dei teatri antichi e moderni (1777), Francesco Quadrio, Della storia e ragione d'ogni poesia (1739-1752).

26. Como él mismo subraya en su réplica a la afirmación de Tiraboschi de haber sido los españoles los causantes de la corrupción de la literatura latina después de la era de Augusto: «Este modo de pensar se funda, si no me engaño, en una falsa inteligencia que dan estos autores modernos a la palabra literatura, limitándola a significar la poesía y la elocuencia. De aquí es que llamen entera decadencia de la literatura a la corrupción del lenguaje, como si los estudios graves, que son la parte más noble de aquélla, no pudieran cultivarse con buen gusto al mismo tiempo que está estragado el de la elocuencia» (Cito por la segunda edición española, Francisco Xavier Lampillas, Ensayo histórico-apologético de la Literatura española contra las opiniones preocupadas de algunos escritores modernos italianos, traducido del italiano por doña Josefa Amar y Borbón, segunda edición: corregida, enmendada e ilustrada con notas por la misma traductora, Madrid, imprenta de Pedro Marín, 1789, I, p. 57. Vid. sobre este punto, Inmaculada Urzainqui, «El concepto de historia literaria en el siglo XVIII», Homenaje al Prof. Álvaro Galmés de Fuentes, Oviedo, Universidad de Oviedo-Gredos, III, 1987, pp. 565-589.

27. Marcelino Menéndez Pelayo, Historia de las ideas estéticas en España, Madrid, Consejos Superior de Investigaciones Científicas, 1974, p. 1329. 
grandes secuencias: "literatura antigua» (desde los orígenes hasta el siglo XIV) y «literatura moderna» (siglos XV a XVIII). Y en las dos se ocupa, en diversa proporción, de la textualidad artística. En la primera, se centra fundamentalmente en poner de manifiesto la antigüedad del ejercicio poético en España apelando a las noticias de Estrabón y Cicerón, en deshacer la imputación de Tiraboschi de que los poetas y oradores de la Hispania romana corrompieron la literatura latina, en reivindicar el valor de los poetas españoles posteriores a la muerte de Augusto -primero, Séneca, Lucano y Marcial, y luego, los que «santificaron las musas romanas» (Juvenco, Prudencio, "príncipe de los poetas cristianos» (II, p. 91, 95), etc.-, en dar noticia de los que también escribieron versos latinos en los siglos inmediatos (Orencio, San Ildefonso, Álvaro Cordobés, San Eulogio, etc.), y en señalar la influencia de la literatura árabe peninsular en la lírica trovadoresca, en cuyo cauce da cuenta también de «nuestros principales poetas lemosinos» («Meser Jorge», Jaime Febrer, Hugo de Mataplana, Ausias March); y en la segunda, en demostrar la calidad de la literatura española en la edad moderna, asunto al que por su importancia reserva íntegramente dos tomos: el V (poesía, en la que incluye también la novela) y el VI (teatro). Dos tomos que de algún modo van a constituirse en una historia general de la literatura española desde el comienzo de las lenguas vulgares, pues aunque el proyecto era situar el campo de observación en esa edad, considera muy a propósito remontarse al pasado y dibujar una panorámica general del «Parnaso español»:

\footnotetext{
Tengo por cierto que los literatos imparciales acogerán benignamente esta parte de apología sobre la poesía y teatro español. Aunque ésta forma principalmente la continuación de la historia española del siglo XVI, sin embargo, ofrece un estado de nuestra poesía en las demás épocas para que se vea reunido como en un punto de vista un ensayo del Parnaso español (V, p. 28).
}

Proceder así, definiendo un "punto de vista» histórico-nacional, le iba a permitir sustanciar su apología desde la misma raíz del conflicto: enfrentando los dos Parnasos, el italiano y el español, para afirmar los valores de la poesía española y desacreditar las falsas ideas acerca de su presunta pobreza, inferioridad y perniciosa influencia. En definitiva, establecer el canon de la literatura española; porque -es la idea fundamental hacia la que apuntan sus consideraciones histórico-literarias- aunque es verdad que Italia ha tenido poetas eminentes y ha ejercido un magisterio inequívoco en la literatura moderna -en la lírica sobre todo- también lo es que España puede competir dignamente con ella e incluso vanagloriarse de haberla superado en ciertos ámbitos como el teatro o la novela. Pero como el juego estaba ya 
repartido y se trataba de eso, de responder a un largo racimo de percepciones erradas, la sistematización de su defensa no consistirá, como he dicho, en seguir linealmente el curso literario español en todos sus detalles, sino en ir contestando a todas ellas en sucesivos capítulos mediante monografías sobre aspectos puntuales, que, en el ámbito de la poesía, llevan aparejados recorridos selectivos por las principales modalidades genéricas -lírica, épica, bucólica, didascálica, sátira, novela («invenciones romanescas»), etc.-, comparaciones con textos similares de la literatura italiana, noticias acerca de su recepción española y europea, y careos con las estimaciones críticas que han merecido las obras de que se ocupa, principalmente de los italianos. Todo, sin abandonar nunca un apasionado registro polémico y echando mano, siempre que la ocasión lo requiere, de noticias y apreciaciones de la crítica europea (Saint Evremont, Rapin, Gravina, Linguet, Fontenelle, Mme. Dacier, Voltaire, Batteux, Brumoy, Pope, etc.) y particularmente, española, como Nicolás Antonio, Mayáns, Sarmiento, Nasarre, Velázquez, Montiano, Bastero, Tomás Antonio Sánchez, Pellicer y Saforcada, Casiri o López de Sedano, con cuyo Parnaso español, recientemente impreso en Madrid en ocho tomos (1768-1778), se alinea en lo fundamental de sus ideas.

En congruencia con su percepción histórica de España, concibe el acervo poético medieval como la suma de todas las manifestaciones que florecieron en suelo peninsular con independencia de la fragmentación política y la lengua en que estuvieran escritas:

\footnotetext{
Inmediato a lo primeros siglos de la poesía moderna, no cedieron los españoles a otra nación en cultivarla con esmero en los diversos dialectos propios de los diferentes reinos en que estaba dividida España, pues interin que los catalanes y valencianos ocupaban distinguido lugar entre los poetas provenzales, no le faltaban los suyos a Castilla, Galicia y Portugal. Apenas se encontrará príncipe español de aquellos siglos, ni entre los condes de Barcelona, ni entre los reyes de Aragón, de Castilla o de Portugal que no fuese protector de la poesía y algunos de ellos también poetas (V, p. 38).
}

De esa literatura -que no pretende abarcar en todos sus extremos, pues el lector podrá conocerla a través de los trabajos de Sarmiento, Velázquez y Tomás Antonio Sánchez- hay dos aspectos que especialmente le interesa destacar: la precedencia y valor de la épica vulgar española frente a la italiana, y la superioridad e influjo europeo de la narrativa de ficción (el Amadis y sus imitaciones). En efecto, así como la poesía italiana sólo puede hacer gala del cultivo de la épica a partir de Pulci, el Parnaso español puede gloriarse de haber tenido su origen en "un ensayo rústico de poesía épica», el largo Poema del Cid recientemente publicado por T. A. Sánchez, sólo precedido 
del fragmentariamente conocido poema de La pérdida de España, que, siguiendo a Faria y Sousa, dice haberse escrito en portugués, en versos de arte mayor, por un poeta español (V, p. 78). A juicio de Lampillas, el del Cid, primer poema épico en vulgar no sólo de España sino de toda Europa, ofrece «aquella venerable antigüedad que preserva de la crítica hasta la misma rudeza, respetada en los versos del Ennio latino" y tiene en su protagonista un héroe semejante al de Virgilio y bastante más digno de la majestad épica que el fantástico Morgante (V, p. 78). Pero no sólo la poesía española puede vanagloriarse de ese poema épico, pues a él siguieron después otros más dignos también de elogio, como la Alexandriada -el Poema de Alexandre que, como Nicolás Antonio, atribuye a Alfonso X (II, p. 31)- donde «se nota ya menos ruda la poesía española y más armoniosa la versificación» (V, p. 79), el panegírico con que Juan de Mena celebró al marqués de Santillana mostrando «la majestad y entusiasmo de que no le habían adornado todavía nuestros poemas más antiguos» (ibid.) y el poema «romancesco de las proezas de Hércules», aquí aludido como compuesto por un anónimo" (ibid.) y en otro lugar atribuido al marqués de Villena (II, p. 31). Y otro timbre de gloria de nuestro patrimonio poético medieval son también las novelas de caballerías - «invenciones romanescas»-, a las que contradiciendo los inveterados prejuicios que venían pesando sobre la narrativa de ficción ${ }^{28}$, asimila también a la literariedad; una modalidad de escritura que los españoles cultivaron con singular acierto -Amadís de Gaula, Esplandián, Tirant lo Blanc...- y con la que influyeron decisivamente en toda Europa, particularmente la primera, que se constituyó en «una fuente inagotable de nuevos romances españoles, estimados y traducidos a porfía por italianos, franceses, ingleses, holandeses y alemanes» (T.V, VII: En los Romances y en las Novelas excedieron los españoles a cuanto habian escrito en este género los extranjeros, p. 169).

En la línea de Sarmiento y Velázquez, entiende también que en el pórtico de la edad moderna la poesía española experimenta una progresiva madurez gracias a la labor de un notable grupo de poetas: «Hacia el fin del siglo XIV y principios del XV hicieron mayores esfuerzos algunos bellos ingenios para hermosear nuestra poesía, la cual se mostró adornada de mayor elegancia en tiempo del rey Don Juan el II, haciéndose escuchar, ya expresando los afectos amorosos en tono más dulce y ya elevando más sublime el canto hacia lo heroico. Esparcieron esta nueva luz sobre nuestra poesía don Pedro

28. Para una valoración de las ideas de Lampillas acerca de la novela en el contexto del debate dieciochesco sobre su legitimación teórica, vid. Joaquín Álvarez Barrientos, «Sobre la institucionalización de la literatura: Cervantes y la novela en las historias literarias del siglo XVIII", Anales cervantinos, XXV-XXVI (1987-1988), pp. 47-63, y La novela del siglo XVIII, Madrid, Ediciones Júcar, 1991, pp. 181-184. 
López de Ayala, el dulcísimo Macías, llamado el enamorado, Juan Rodríguez del Padrón, Micer Francisco Imperiali, noble ginovés, poeta que se vistió de laureles en España, el Marqués de Santillana, Garcisánchez y Juan de Mena, sin contar otros cuyas poesías se hallan en las colecciones antiguas de versos españoles con el título de cancioneros» (V, pp. 60-61). Pero al igual también que ellos, para él la página más brillante de la literatura española se escribió durante el siglo XVI y principios del XVII, auspiciada por la identificación con el espíritu y expresividad de los clásicos e italianos:

\footnotetext{
Adquirió nuevo esplendor la poesía española en el siglo XV, bajo la protección de don Juan el II, Rey de Castilla, cuyo esplendor fue como la aurora de aquel resplandeciente día que amaneció sobre nuestro Parnaso al principio del siglo XVI, gracias a los felices ingenios de Boscán, de Garcilaso y de sus nobilísimos imitadores, que hermosearon nuestras Musas con todos aquellos atractivos que ostentaron las Musas griegas, latinas e italianas. Por eso se formó en Espańa un nuevo Parnaso, capaz de competir con el italiano, y tal que no podría sufrir entrar en comparación aun con el de las más cultas naciones modernas (V, p. 38).
}

Emergió así un nuevo Parnaso, que por su extraordinaria calidad puede con toda justicia equipararse al italiano. Pero Lampillas no pretende hablar de todos sus componentes. Aunque no deje de precisar, apelando a lo ya indicado en tal sentido por Sedano, que el elenco podría extenderse a muchísimos poetas más "que ocuparon asiento en nuestro Parnaso», concreta selectivamente en unos cuantos nombres las figuras más eminentes, tanto en la lírica como en las demás modalidades genéricas. En primer lugar, Boscán y Garcilaso, los «dos ilustres restauradores de la poesía española» que fueron los primeros en recibir los rayos de la "copiosa luz» de los italianos, y después de ellos, Camoens, Fray Luis de León, Ercilla, Herrera, los Argensola, Villegas, el Príncipe de Esquilache, Barahona de Soto, Jáuregui, Aldana, Lope de Vega, Quevedo, Góngora y algunos otros más. De Garcilaso, digno ciertamente "de ser venerado como padre de la lírica espańola» (V, pp. 111112), sobresalen especialmente la canción V A la flor de Gnido por su belleza y sublimidad (ibid.) y sus églogas, en las que incluso llega a mejorar los pensamientos de los antiguos a los que imita (V, p. 127). Camoens, al que con sutil matiz califica como "Homero y Virgilio de las Espańas», fue "tan ingenioso y tierno en la lírica como majestuoso en la épica» y sobresalió en todo género de poesía (V, p. 113). A mayor altura llegó aún la lírica española con «el incomparable» Fray Luis de León, justamente venerado «como uno de los primeros ilustradores del Parnaso español»; dotado de extraordinario ingenio y lleno de sagrado numen, logró con su poesía que España nada 
tuviera que envidiar a Grecia o Roma por su Píndaro o su Horacio (ibid.). Herrera, que al conocimiento de las lenguas antiguas y modernas unió un fino gusto en la poesía y una crítica exacta de los poetas, mereció por la elegancia y numen poético de sus poesías el honroso título de "el Divino" (V, p. 115). El «muy noble y suave» Francisco de Figueroa, «delicia de las musas y de las gracias», escribió poemas que «respiran por todas partes un aire de dulzura que enamora» (V, p. 116). Los Argensola, "dos ingenios celebradísimos, de los cuales recibió nuevos adornos la poesía española»; la sublimidad, buen gusto y fantasía bien arreglada de sus sonetos y canciones les adquirieron «un honroso asiento entre los príncipes de la lírica española» (V, p. 117), distinguiéndose también con «sus delicadas sátiras» (V, p. 147). Príncipe igualmente de la poesía fue Quevedo, «gloria singular de la literatura española de los siglos XVI y XVII», "prodigioso ingenio» que supo unir el entusiasmo, la elegancia y las gracias de los griegos, latinos e italianos; aunque sobresalió en todo género de poesía, lo hizo especialmente en las que dio a luz - así lo cree- con el nombre de Francisco de la Torre (V, p. 118), en la sátira, tanto en prosa como en verso - «en algunas de ellas declama contra los vicios con toda la autoridad del más rígido estoico» y en otras en las que, depuesto el manto filosófico, "se vale de las chanzas y ridiculiza los vicios con una gracia inimitable» (V, p. 147-148)-, en la didascálica y en la burlesca (V, p. 142, 250). Villegas, "el dulcísimo Anacreonte español», dio testimonio con sus composiciones de la suavidad y hermosura de la lengua castellana (V, p. 121) y escribió también sátiras excelentes (V, p. 147). El príncipe de Esquilache es «uno de los más nobles poetas de la primera esfera de que con justicia hace vanidad la nación espańola» (V, p. 121). Lope de Vega, el ingenio "más fecundo de cuantos vio la edad antigua y moderna», enriqueció la poesía con un portentoso número de composiciones, entre las que destacan particularmente sus odas y canciones, tal vez «en las que menos puede hallar que censurar la más escrupulosa crítica»; formado con el estudio e imitación de los griegos y latinos, "supo copiar las excelencias de unos y otros» (V, p. 123) y con su poesía burlesca, «mereció ser coronado por príncipe» en esta clase, en la que excedió a todos (V, p. 148). Otro autor que también se distinguió en este tipo de poesía fue el conquense José de Villaviciosa gracias a su Mosquea, "obra escrita con elegancia y chistes ingeniosos» (V, p. 149). El «sobresaliente ingenio cordobés» Luis de Góngora, talento singular «criado para ser uno de los mayores ornamentos del Parnaso espańol», aunque "el deseo de hacerse cabeza de una nueva escuela le indujo a abrazar el estilo hueco, oscuro y fantástico con que fundó la nueva secta de los llamados poetas cultos», cuando abandonó este estilo y escribió con naturalidad, elegancia, armonía y delicado numen poético, «no fue inferior a otro alguno 
de nuestros poetas», distinguiéndose particularmente en las sátiras jocosas, "dignas del más ameno ingenio», en algunas canciones breves, "dignas de la mayor dulzura» (V, p. 148) y en la poesía burlesca (V, p. 150). Menciones elogiosas merecerán igualmente La Araucana de Ercilla, «el segundo Virgilio español, escrita "con singular pureza de estilo, elocuencia de versificación, variedad de episodios y abundancia de máximas morales y políticas» (V, p. 96), los poemas caballerescos («invenciones romanescas») de Barahona de Soto, Francisco de Aldana y Martín Abarca de Bolea, las fábulas mitológicas Píramo y Tisbe de Montemayor, Apolo y Dafne de Agustín Collado, Venus y Adonis del "amenísimo» Alfonso de Batres y especialmente, el Orfeo de Jáuregui, «que excedió a todos» (V, pp. 150-151), la poesía religiosa de Bernardino de Rebolledo, digna «de colocarse en los primeros lugares del Parnaso sagrado» (V, p. 139) y los «cuentecillos fabulosos» en estilo jocoso de Polo de Medina, Barahona de Soto, Pantaleón de Ribera y Góngora.

Pero el Parnaso español no se reduce a esos autores insignes. En su afán por reclamar el mérito de nuestra literatura, observa que también contribuyeron a enriquecerlo quienes acertaron a traducir "con suma elegancia» a los mejores poetas antiguos y modernos -Fray Luis, Cristóbal de Mesa, Villegas, Jáuregui, Figueroa... (V, VI: Los poetas españoles no cedieron a los de otra alguna nación en el empeño de poner en versos españoles las mejores poesias extranjeras antiguas $y$ modernas) - y, lo que es más significativo por lo novedoso de incorporar el segmento femenino a la historia literaria, muchas mujeres, como Luisa Sigea, la portuguesa Bernarda Ferrerira de la Cerda, que escribió en español «un poema elegante y bien seguido con el título de La España libertada» y sendos tomos de comedias y poesías, así como otras «muchas elegantísimas musas» de que hace honrosa mención, dice, el valenciano Pablo Ribera ${ }^{29}$ (T. IV. Apéndice a la literatura española del siglo XVI. Las mujeres ilustres españolas no cedieron a las italianas en el cultivo de las letras, así sólidas como bellas).

Y aun hace más. Convencido igualmente de la legitimidad poética de la narrativa de ficción y molesto por el desinterés de los italianos hacia la española en particular, la incorpora a ese cuadro general para que quede constancia de «las primorosas producciones de nuestros escritores amenos». En continuación a lo ya dicho sobre la narrativa medieval, atiende tanto al cuento («novela»), representado por Cervantes, Lope de Vega, Pérez de Montalbán,

29. Debe de referirse al jesuita mallorquín contemporáneo del mismo nombre. Ignoro a qué obra se refiere. Todas las que registran José María Bover y el Espasa, que dejó manuscritas, son filosóficas. No lo mencionan el P. Batllori ni Aguilar Piñal. La portuguesa Bernarda Ferreira (1595-1645), aya de los hijos de Felipe III, escribió, en efecto, las obras que cita. Lope la elogia en El laurel de Apolo. 
Castillo Solórzano y María de Zayas, como a la novela propiamente dicha («romances»). De entre las varias que menciona, destacan particularmente el Lazarillo, que atribuye a Hurtado de Mendoza - «¡y a dónde no llegó la fama del graciosísimo romance El Lazarillo de Tormes, obra del ingenio ameno de Don Diego Hurtado de Mendoza?»-, el Guzmán de Alfarache, obra del «sobresaliente ingenio» Mateo Alemán, y de manera muy especial El Quijote del «inmortal» Cervantes, que es la que para él merece el puesto de mayor distinción por la suma de cualidades admirables que se congregan en ella: una poderosa creatividad sabiamente contenida en los límites de la verosimilitud, un estilo excelente que hace que hoy se le lea con la misma complacencia que en su tiempo, gracia, "artificio" para saber continuar una fábula que parece debía haberse concluido desde la primera aventura, y un fin utilísimo cual fue el de desacreditar, mediante una magnífica sátira, las novelas de caballerías. "Romance lleno de mil preciosidades y gracias, de una invención felicísima, de un estilo puro, natural y copioso de chistes» (V, p. 173-174), es «una de aquellas pocas obras de ingenio que hacen inmortal el nombre del autor» (V, p. 176) y, sin lugar a dudas, la producción más original y suprema del género:

\footnotetext{
Él abrió un nuevo camino a las aventuras romancescas, sin tener que cavar las minas ajenas, para adornar su Quijote con piedras preciosas, porque tenía un fondo inagotable en su fecundísima imaginación. Por otra parte, no es difícil crear nuevas invenciones cuando se deja correr la imaginación más allá de los límites de lo verisímil y aun de lo posible; estos descubrimientos, por más que embelesen al vulgo, no convienen para producir deleite en los lectores sabios. Lo que se debe aplaudir es aquella imaginación feliz que nos deleita y encanta con prodigiosa variedad de sucesos maravillosos y agradables, sin ofender, no digo lo posible, más lo verosímil. Esta es la circunstancia que hizo a Cervantes superior al Ariosto y a los otros romanceros (V, p. 178).
}

Por todo eso no hay ninguna obra antigua ni moderna que pueda parangonarse con ella: «si hablamos de historias caballerescas y novelas, ¿quién se atreverá a competir con Cervantes? (II, p. 222). Prueba incontestable de esa altísima calidad es el aplauso y difusión que ha logrado en todas partes.

Finalizada su panorámica general de las obras y autores más sobresalientes de ese venturoso tiempo, y antes de pasar al teatro, para corroborar su mérito incluye al final del tomo $\mathrm{V}$ una selección de poesías de los Siglos de Oro («Ensayo de poesías espańolas») que, procedentes en su mayor parte del Parnaso de Sedano, había traducido al verso italiano su compañero de orden y de exilio Juan Francisco Masdeu y que poco después éste editaría, 
junto con otras más, en el volumen de Poesie di ventidue autori spagnuoli del Cinquecento (1786). Esta selección, que en la versión española Josefa Amar devolvió a su forma original, reúne textos de Boscán, Garcilaso, Camoens, Fray Luis de León, Figueroa, Herrera, los Argensola, Quevedo, Lope, Villegas, Esquilache y Francisco de Rioja, acompañados en bastantes casos de comentarios encomiásticos.

Entrando ya en la poesía dramática, el trabajo de Lampillas se despliega en tres frentes prioritarios: intentar mostrar su cultivo a lo largo de la historia, poner de relieve la precedencia espańola en el teatro regular (La Celestina, tragedia del Renacimiento) y en el drama "pastoril»(Juan del Enzina, la égloga II de Garcilaso, Lope de Rueda), y defender la dramaturgia de Lope y sus seguidores destacando los valores que, por encima o más allá de la irregularidad que le imputan los críticos italianos, se hallan en sus obras (invención, pintura natural de caracteres, buena estructuración, versificación elegante y armoniosa, acertado estilo, etc.), minimizando a cambio esos defectos y proclamando que "la comedia española desde el tiempo de Lope de Vega hasta cerca de la mitad del siglo XVII forma una nueva época del teatro, superior a todas las antecedentes desde la restauración de las letras»; un teatro que mitigando en parte el rigor aristotélico supo, con la multitud y enlace de sucesos, divertir a un público ya «fastidiado de los espectáculos antecedentes» (VIII, X). En esta parte sin embargo, más volcada en la cruzada ideológica que en la verticalidad narrativa, la nómina de autores es sensiblemente inferior a la anterior. En la España romana menciona a Marco y Lucio Séneca, de quienes recuerda que se les atribuyen ocho de las diez mejores tragedias latinas conservadas, y ya al comienzo de la restauración de las letras, después de un largo período que se esfuerza en rellenar con los escasos datos conocidos y las conjeturas de Nasarre acerca de las representaciones dramáticas de los árabes, Juan del Enzina, «en quien ya se ve despuntar un delicado gusto de poesía» (VI, p. 53), el primer autor-Mena o Rodrigo de Cota- de La Celestina y, en menor medida, su continuador, pues aunque tan diestro como el primero en el estilo y viveza de descripciones, transformando el texto en tragicomedia lo convirtió en una obra «monstruosa y desarreglada»:

Otro más bello ensayo teatral tuvo España a mitad del siglo $\mathrm{XV}$, con el cual puede pretender haber conocido antes que Italia el arte cómico. Hablo del acto primero de la comedia intitulada $L a$ Celestina, por otro nombre Calixto y Melibea. Se empezó y prosiguió hasta el segundo acto esta composición dramática pasada la mitad del siglo XV, siendo su autor Juan de Mena o más bien Rodrigo de Cota. Sea quien fuere el autor, lo cierto es que da a conocer 
estaba perfectamente instruido en el arte de la verdadera comedia. La elegancia de estilo, la facilidad diestra del pincel en retratar los caracteres al natural aseguran sin disputa a aquel primer acto la gloria de ser el primer trozo de composiciones teatrales que se vio hasta entonces competir con las comedias latinas y griegas. A los fines del mismo siglo tomó a su cargo Fernando de Rojas el concluirla, y aunque no es muy inferior al primer autor en locución y viveza de las descripciones, lo es muchísimo verdaderamente en el arte teatral, pues la composición que empezó comedia [...] la concluyó el continuador en tragedia, y por esto le pareció denominarla tragicomedia, con lo que vino a quedar monstruosa y desarreglada una composición bella y regular en su principio (VI, pp. 53-54).

En el XVI, son los trágicos conocidos a través de las investigaciones de Montiano los que acaparan sus mayores complacencias y le permiten desmentir la presunta inhabilidad española para la tragedia: Fernán Pérez de Oliva, autor, que no traductor como se dice, de las primeras tragedias arregladas, Juan de la Cueva - «su talento poético ilustró desde su mocedad todo género de poesías y enriqueció el Parnaso español con elegantísimas composiciones» (VI, p. 90)-, Jerónimo Bermúdez, Rey de Artieda, Lupercio L. de Argensola y Virués. Pero también muestra su estima por Lope de Rueda, «excelente poeta» al que «todos nuestros autores antiguos le conceden la gloria de primer restaurador del teatro español» (VI, p. 158), Cristóbal de Castillejo y el primer Cervantes. Como le resulta incomprensible que alguien de su talento y conocimiento del arte compusiera las «extravagantes» y desatinadas comedias de la edición de 1615, avanza la hipótesis de que no fueron en realidad obra suya sino de la malicia de los impresores. En cuanto a los dramaturgos de la comedia nueva, como se mueve en un terreno de consideración general, hace muy pocas referencias concretas. Fuera de Lope, "padre del nuevo teatro» y de Calderón, que son quienes encarnan sus característicos méritos de talento, fuerza inventiva, habilidad en el enredo, buena versificación, etc., los autores que menciona, sin entrar en comentarios críticos de sus obras, son los que han logrado mayor aprecio y difusión en Europa: Moreto, Solís, Rojas Zorrilla, Ruiz de Alarcón, Pérez de Montalbán, Matos Fragoso y unos pocos más.

Por más que el registro polémico se imponga sobre el estrictamente historiográfico y las páginas del Ensayo estén lejos de ser, como el propio Lampillas reconoce, un completo panorama del Parnaso español, es indudable que para sus lectores, italianos en primera instancia y luego españoles, además de un vigoroso alegato a favor del derecho de España a contarse entre las naciones más cultas, vino a ser un magnífico ventanal por el que asomarse a sus trazos más acusados y representativos. Pero mucho 
más -con mayor riqueza de noticias y referencias críticas- y en términos muy distintos (aunque compartiendo un común afán por contrarrestar las ideas equivocadas de los detractores de la cultura española) es lo que hará su compañero de exilio en la magna obra que empieza a publicar, también en Italia (Parma), un año después de finalizada la suya.

\section{Juan Andrés}

En efecto, las palabras con las que Juan Andrés abre su Dell'origine, progressi e stato attuale d'ogni letteratura (1782-1799), casi inmediatamente traducida al español por su hermano Carlos (Origen, progresos y estado actual de toda la literatura, 1784-1806), resumen expresivamente el carácter y magnitud de su empresa: "Una historia crítica de las vicisitudes que ha sufrido la literatura en todos tiempos y en todas las naciones; un cuadro filosófico de los progresos que desde su origen hasta el día de hoy ha hecho en todos y cada uno de sus ramos; un retrato del estado en que se encuentra actualmente, después del estudio de tantos siglos» ${ }^{30}$. Porque eso es realmente esa obra singular: un formidable esfuerzo intelectual para dar cuenta, en un relato razonado y crítico, del devenir cultural de la Humanidad desde el más remoto pasado hasta la actualidad. Un intento «tal vez demasiado temerario y atrevido", como él mismo reconoce, al que se lanza en su exilio italiano sin precedente alguno ni más medios que su talento, un más que mediano conocimiento de los materiales bibliográficos necesarios para su trabajo y una prodigiosa capacidad de síntesis.

Al igual que los Mohedano y Lampillas, por literatura entiende todo el caudal de artes y ciencias que el hombre ha ido atesorando con el correr del tiempo («después del estudio de tantos siglos»). Para sistematizar su análisis, tras sopesar distintas posibilidades y descartar la acreditada clasificación de Bacon, abrazada después por los autores de la Encyclopédie, decide organizar la exposición en dos partes: «Buenas Letras» o «Letras humanas» y Ciencias, éstas divididas a su vez en Naturales y Eclesiásticas. La primera, que es la que

30. Cito por la edición moderna: Juan Andrés, Origen, progresos y estado actual de toda la literatura. Traducción de Carlos Andrés, ed. J. García Gabaldón, S. Navarro Pastor y C. Valcárcel Rivera, dirigida por P. Aullón de Haro, Biblioteca Valenciana-Verbum Editorial, 2000, «Prefación del autor», p. 8. Para un análisis más pormenorizado del carácter y significación de la obra, vid. Pedro Aullón de Haro, «Juan Andrés: Historiografía, enciclopedia y comparatismo: la creación de la Historia de la Literatura Universal y Comparada», en Pedro Aullón de Haro, Jesús García Gabaldón y Santiago Navarro Pastor (eds.), Juan Andrés y la teoría comparatista, Valencia, Biblioteca Valenciana, 2002, pp. 17-26 y el Estudio preliminar a la mencionada edición. 
aquí nos interesa, comprende cuatro grandes apartados: poesía, elocuencia, historia (incluyendo la geografía, cronología y anticuaria), y estudios filológicos (gramática, exegética y crítica). Los dos primeros contemplan lo que hoy llamaríamos, por su intencionalidad artística, literatura propiamente dicha, esto es, la poesía -en la que incluye también la novela, toda vez que le otorga el estatuto de "obra poética»- y la prosa literaria o elocuencia ${ }^{31}$, y los otros dos, los estudios humanísticos (historia, geografía, filología). Ello no quiere decir, sin embargo, que englobe en una misma categoría a poetas y prosistas, pues para él pertenecen a dos esferas distintas del arte de la palabra, como se hace patente cuando echa mano -con no poca frecuencia, igual que Lampillas- de la noción de Parnaso, con la que alude exclusivamente al conjunto de los poetas. A partir de esta clasificación, ofrece, primero y a modo de pórtico, una panorámica general de la historia de la cultura en todas sus épocas, y luego, el examen particular de cada una de sus "clases»; lo que determina un doble tratamiento histórico de la poesía: el que aparece embebido en el cuerpo de esa panorámica, y el que recibe en su parte específica, organizado también en dos partes, por naciones y según los diferentes géneros literarios (épica, didascálica, dramática, lírica, égloga, elegía, sátira, novela («romances»), etc.). Si en el primero, como cabía esperar en un enfoque universal de la cultura, la poesía española apenas va más allá de un rápido apunte de sus trazos más significativos, en el segundo, avistada ya desde la perspectiva específica del arte literario, afirma su entidad y se despliega en términos más ricos y matizados, particularmente la referida a los siglos XVI y XVII, que es la que recibe mayor atención.

Resuelto con esa clasificación un primer problema metodológico, otro que también tuvo que afrontar -aunque no hable específicamente de ello-fue el de elegir el criterio para construir el escenario de su indagación histórica, es decir, decidir cómo fragmentar las diferentes geografías o ámbitos nacionales del progreso cultural en tanto en cuanto su designio no era proceder in genere sino concretar el análisis «en todos tiempos y en todas las naciones». $\mathrm{Y}$, ¿cuáles son esas naciones? A tenor de los epígrafes que jalonan el desarrollo expositivo, el lector advierte, efectivamente, que el autor desglosa diversas unidades de consideración que en general vienen a coincidir con los distintos

31. «... Nosotros, que ahora restringimos el nombre de Elocuencia a la Prosa» (Origen, III, p. 18). Bajo una clasificación de la elocuencia en siete ramas (forense, didascálica, dialogal, epistolar, elogios y sagrada), registra obras de muy variado signo: filosóficas, históricas, didácticas, científicas, oraciones públicas, diálogos, epístolas, elogios, sermones, discursos, libros de máximas y sentencias, informes, ensayos periodísticos, etc. Así, bajo la rúbrica de "elocuencia didascálica», alude a las obras de Feijoo y al ensayismo crítico de Addison y Clavijo y Fajardo. 
pueblos y territorios históricos que han dejado alguna huella cultural -China, India, Egipto, Persia, Grecia, Roma, árabes, fenicios, hebreos, etruscos, Francia, Inglaterra, Alemania, España, Italia, etc.-, porque, como él mismo se encarga de puntualizar, de los demás nada se puede decir («ni menos hablaré de los etíopes y demás naciones antiguas de África, porque ¿qué noticias podremos dar que sean gloriosas a su literatura y puedan apoyarse en sólidos fundamentos?», I, p. 28). La única excepción a esa sistematización por países o culturas nacionales la constituye la literatura eclesiástica, una categoría supranacional que introduce para aludir al «nuevo ramo» de cultura que genera el cristianismo (apologías, exégesis de la Biblia, teología, poesía sagrada, derecho canónico, historia de la Iglesia, etc.); un ámbito, que al igual que el de las naciones, cuenta también con su propio Parnaso poético, iniciado en su caso justamente por un poeta español, Juvenco:

¿Y por qué no podremos añadir a tantos méritos del siglo IV el de haber reducido a las Musas a hacerse cristianas y obligado a la Poesía a aprender el lenguaje de la verdadera Religión? El español Juvenco fue el primero que pisó este incógnito campo y pudo alabarse, con más motivo que el romano filósofo Lucrecio, de haber abierto en el Parnaso un camino hasta entonces desconocido, de haber bebido de fuentes que ninguno había probado y de haber cogido flores del todo nuevas con que tejerse una insigne corona para su cabeza cual nunca habían formado las Musas para ceñir la frente de otro alguno (I, 87).

¿Pero quiénes son los que específicamente forman el Parnaso español? Según los datos y referencias que vamos viendo desfilar por sus páginas, advertimos que aunque indudablemente la nómina es bastante extensa, está lejos de ser exhaustiva. Tampoco él lo pretendía. Ni en el caso de España ni en el de ninguna otra nación. Siendo muy consciente de la envergadura de su proyecto y de las muchas aportaciones que han ido adelantando el conocimiento de la poesía, sobre todo en sus edades más remotas, renuncia a emprender investigaciones para sumar nuevos nombres a los ya conocidos $y$, en vez de un recuento detallado, opta por circunscribirse a los de mayor relevancia y significación -«aquéllos que han tenido mayor influjo y que más deben interesar al común de los literatos» (I, p. 18)-, que son a los que por ello otorga el calificativo de «clásicos» apelando a una voz ya consagrada con tal sentido en la tradición humanista ${ }^{32}$ :

Ojalá hubiese podido tratar los asuntos con una plena exactitud y presentar un perfecto cuadro de las Buenas Letras capaz de satisfacer el sano juicio y el fino gusto de los eruditos lectores. Ciertamente

32. Cfr. R. Wellek, «El concepto de clasicismo en la historia literaria», en Historia literaria. Problemas y conceptos cit., pp. 103-104. 
lo he procurado con gran solicitud y, a este fin, no contentándome con observar atentamente el curso de las Buenas Letras en todas las naciones cultas, me he propuesto examinar con diligencia el mérito de los escritores principales que han contribuido a las vicisitudes de algunas de sus partes [...] Busquen, pues, otros semejantes noticias, que pueden dar algún ornamento a la literatura patria o mayor ilustración a algún punto de Historia; pero nosotros, que examinamos los progresos que han hecho las Buenas Letras, no debemos atender a los nombres desconocidos y obscuros, más sí fijar nuestra consideración en los autores clásicos y examinar con mucha atención el verdadero mérito de cada uno de ellos. He creído que éste debía ser mi empeńo y que a él debía dirigirse principalmente mi estudio» (II, p. 15).

En efecto, congruente con este criterio selectivo-canónico, recorre la experiencia poética española fijándose únicamente en los autores más notables, tanto en el contexto literario de su tiempo como en el de cada una de las modalidades genéricas que contempla. Para ello cuenta, además del conocimiento directo de una gran parte de los textos que menciona, con un amplio bagaje de estudios y repertorios, tales como las Anotaciones de Herrera a la poesía de Garcilaso, el prólogo de Cervantes a sus obras dramáticas, la Biblioteca de Nicolás Antonio, los trabajos más recientes de Mayáns, Luzán, Sarmiento, Nasarre, Montiano, Velázquez, Casiri, Cerdá, Bastero, T. A. Sánchez, Rodríguez de Castro, Lampillas, etc., así como las obras de autores extranjeros que de un modo u otro han recalado en la poesía española (Huet, Millot, Peyron, Muratori, Tiraboschi, Massieu, Quadrio, Pedro C. Decembrio, Napoli-Signorelli, etc.).

El servirse de un doble itinerario -como Velázquez y Lampillas-, y el considerar el hecho literario español dentro del cuadro general de la poesía de las «naciones cultas», con frecuentes cotejos entre unos autores y otros, conforma un singular sistema discursivo en el que nuestro patrimonio literario, lejos de ofrecerse como un relato seguido y lineal, aparece dosificado en fragmentos discontinuos. Pero sin que de ello deje de resultar una imagen suficientemente trabada y coherente.

A diferencia de Sarmiento, los Mohedano y Lampillas que optan por el criterio histórico y tratan de indagar el origen de la poesía española en el más remoto pasado, él prefiere buscarlo en los comienzos mismos de las lenguas vulgares: en la canción del portugués o gallego Gonzalo Hermíguez de mediados del XI, ya citada por Sarmiento, en el Poema del Cid, al que considera el poema castellano más antiguo que se conoce (separándose de la opinión de T. A. Sánchez, que lo data a mediados del XII, lo adelanta a finales del XI o principios del XII), y en una poesía inmediatamente anterior 
sobre la que hasta el momento sólo hay noticias vagas e imprecisas ${ }^{33}$. A partir del ahí, la denominación de "poesía española» quedará asimilada a la castellana, viniendo a coincidir así con el planteamiento básico de Luis José Velázquez. Hay, sin embargo, una diferencia radical que le separa de él, pues si su predecesor extendía el cuadro de la literatura española a esas otras «fuentes» que habían contribuido al desarrollo de la castellana, él opta por adscribirlas a otros ámbitos poéticos. Según los epígrafes que marcan sus categorías de clasificación, se podría decir que todo lo producido en suelo peninsular antes y después en otras lenguas distintas del castellano no tiene para él la condición de español, pues no es reclamado como tal en el haber de su Parnaso. Así, Lucano, Marcial o Séneca forman parte de la literatura «romana», Juvenco y Prudencio de la «eclesiástica», los que escriben en tiempos de la dominación árabe, de la «arábiga» - por más que resalte el poderoso influjo que esta cultura llegó a tener sobre los «españoles» y europeos- los que lo hacen en lemosín o catalán adhiriéndose a la poética de los trovadores, como Ausias March o Jaime Roig, serán ahijados a la poesía «provenzal», aun cuando también crea, en la línea de Lampillas, que tanto la lengua como la poesía provenzal son originarias de Espańa (I, p. 243-245), y las traducciones de Villegas, a la poesía latina en vulgar del siglo XVI (I, p. 309). Por eso, ninguna de estas literaturas -como tampoco la que antes se produjo en suelo peninsular o la escrita en portugués o vascuence, a las que ignora, excepción hecha de Camoens ${ }^{34}$, por completoentran a formar parte de la "poesía espańola» cuando específicamente trata de ella. Lo que no significa, claro está, que deje de reconocer la condición de «españoles» a todos esos poetas. La citada referencia al «español Juvenco» y otras muchísimas más de parecido tenor afirman claramente su inequívoca conciencia nacional. Hay que pensar, pues, que si procedió así, excluyendo de su narración histórica nacional las otras literaturas hispánicas, no fue porque renunciara a ellas o esa conciencia se hubiera disuelto, sino porque debió

33. Se refiere, por un lado, a los versos de la canción de Figueroa que cita el P. Brito y al poema sobre la pérdida de España que a su vez menciona Manuel de Faria en sus comentarios a las rimas de Camoens. Aunque expresa serias dudas sobre la antigüedad que se les atribuye, considera que «indubitablemente son antiquísimas» (II, p. 230); y por otro, a la cancioncilla sobre la derrota (998) de Almanzor en "Calcanasor» (Calatañazor), que menciona el P. Mariana y que para él es indicio de la existencia de una temprana poesía en vulgar. A falta de mayores certezas, concluye: «Por lo cual, considerando lo que se diferencian las lenguas modernas septentrionales de las usadas en los escritos anteriores al siglo XI, y no hallando en las meridionales monumentos seguros y auténticos de aquellos tiempos, podremos fijar el principio de la cultura de las lenguas y de la Poesía vulgar en el siglo XI» (I, p. 225).

34. Al que se refiere, como portugués, al tratar de la épica. Pero sin dedicar ningún apartado específico a la poesía portuguesa, que queda al margen de sus consideraciones. 
entender que, metodológicamente, era la sistematización más adecuada para exponer el flujo general de la literatura.

En términos generales, su visión histórico-crítica de la poesía española no es muy distinta de la de Velázquez y Lampillas. También para él el arte literario llega a su plenitud en el siglo XVI -el «siglo de oro»-, ese tiempo en que los espańoles cultivan todos los géneros «con laudable felicidad», e inicia su decadencia en el siguiente:

España fue la primera nación que abrazó el ejemplo de la Italia, y, en efecto, la lengua española es la única que, como la italiana, cuenta por su siglo de oro al siglo XVI. Pero tanto los italianos como los espańoles decayeron de su esplendor literario en el siglo siguiente y cedieron el lugar a los franceses, sus secuaces (II, p. 27).

Lo anterior fue un lento proceso de crecimiento en el que no cabe reconocer ninguna obra maestra, aun cuando no deje de haber algunas figuras destacables. El Poema del Cid, el de Alejandro y otros por el estilo, dice, que se oían en Espańa en los siglos XII y XIII «y ahora los conservan los eruditos para conocer las primeras gracias de la Poesía», eran en realidad unas «composiciones informes» que en modo alguno merecen el sagrado nombre de poemas épicos (II, p. 119). Berceo y el autor del Alexandro tienen el mérito de haber dado mayor exactitud y regularidad a la versificación (II, p. 65). Alfonso $\mathrm{X}$ enriqueció la poesía «con nobles imágenes y con altos pensamientos, singularmente en el fragmento conservado del libro de Las querellas, en el que se encuentra una sublimidad que nada tiene que envidiar a las grandiosas expresiones del célebre Dante» (ibid.). Mientras éste escribía, Juan Ruiz, Arcipreste de Hita, «divertía en España con amenas y graciosas burlas, e introducía en la Poesía las agradables invenciones y los donosos juegos que no eran aún conocidos en ella»; con la contienda entre el Carnaval y la Cuaresma -fábula bien seguida y llena de episodios ingeniosos- dio el primer ejemplo de poesías jocosas que se conoce en lengua vulgar, y el episodio del recibimiento de $\mathrm{D}$. Amor respira tal amenidad de imaginación y tal copia de ideas y de expresiones que se podría contar entre las composiciones clásicas y magistrales si hubiera tenido algo más de cultura en la lengua y más armonía en los versos (ibid.). De los poetas del XV, época ya de una poesía más madura y formada (I, p. 297), merecen reconocimiento los «armoniosos versos» de Rodríguez del Padrón, Diego de San Pedro y Pérez de Guzmán (ibid.), la sublimidad y brío poético de las composiciones de Juan de Mena, particularmente el Laberinto de fortuna y la Coronación(II, p. 65), y la grandeza de los sonetos Santillana, a quien hay que alabar -dice siguiendo la metáfora de Herrera- por haberse engolfado venturosamente en un mar no conocido 
y haber vuelto a su nación con los despojos de peregrinas riquezas (ibid.). En ese tiempo podría situarse también el origen del teatro español, según las noticias que aportan Lampillas -Enrique de Villena, Juan del Encina-y una referencia de Jaime Roig, que recientemente ha comunicado a su hermano Carlos el erudito canónigo Antonio Mayans, acerca de un posible teatro en valenciano (II, pp. 239-40). Pero como no conoce directamente ni esos textos ni La comedieta de Ponza de Santillana que los españoles, dice, ponen en el número de las composiciones dramáticas del siglo XV, prefiere pronunciarse únicamente sobre la obra que está en manos de todos: La Celestina. En el amplio comentario que le dedica, además de resaltar su amplia difusión y la unanimidad de la crítica en valorar la elegancia y propiedad de su estilo así como la gracia del diálogo, celebra la naturalidad y verosimilitud de su acción, la buena pintura de sus personajes, y la considera como la primera creación regular del teatro moderno: "contiene una acción bien desenvuelta y expuesta con episodios verosímiles y naturales, pinta con exactitud las costumbres y los caracteres, y a veces expresa con viveza los afectos; todo lo cual será, en mi juicio, bastante para darle la gloria de haber sido la primera composición teatral escrita con elegancia y regularidad». Cree, no obstante, que su larga extensión "y algunos pasajes sobrado deshonestos» hacen que no sea para representarse (II, p. 241-242).

Entrado ya en el «magnífico cuadro» del siglo XVI, el panorama se amplía y diversifica con la memoria de sus ingenios más esclarecidos. Boscán tiene el doble mérito de haber sido el primer poeta «del nuevo gusto" y de haber allanado el camino a Garcilaso, reconocido con toda verdad "príncipe de la poesía espańola» -y aun quizá «de toda la poesía si una muerte prematura no lo hubiera arrebatado en lo más florido de su edad»- por haberle hecho remontar el vuelo emulando a los más célebres latinos e italianos y darle «una gracia y armonía no conocida hasta entonces»(II, pp. 66-67). A él se deben las mejores églogas castellanas, aun cuando no sean del todo perfectas (II, p. 355) y elegías escritas «con pureza de lenguaje y elegancia de estilo (II, p. 368). De entre los poetas que le siguen, destacan «el docto y agudo» Hurtado de Mendoza, que mostró espíritu, erudición y copia de sentencias aunque no puso todo el cuidado necesario en la corrección y suavidad del verso, «el culto y delicado Cetina», que cantó al amor con suavidad propia del Petrarca, fray Luis de León, un poeta de gusto diverso al de los otros que quiso expresar en sus canciones «no la ternura y el amor de Petrarca, sino el nervio y el espíritu de Píndaro y de Horacio» (II, p. 343), Herrera, Medrano, Figueroa y, particularmente, varios poetas que escribirán a finales de siglo y comienzos del siguiente que son los que para él representan la cima de la poesía española: Villegas, incomparable émulo de Anacreonte, los dos 
Argensola, que «por la nobleza de los pensamientos, por la naturalidad de los afectos, por la elección de las expresiones y por la cultura del estilo, gozan en compañía de Garcilaso el principado de la Lírica española» (II, p. 343), y «el famoso" Lope de Vega, un poeta de talento extraordinario que de no haber sido tan pródigo en sutilezas y afectaciones verbales habría sido, no ya solo el príncipe de los líricos españoles, sino tal vez de todos los modernos:

Ilustrada de este modo, la Poesía espańola fue adquiriendo en todo aquel siglo más gracia y belleza, y a fines de él y a principios del siguiente brilló mucho más y compareció en su mayor decoro. Villegas, los dos Argensola y otros poetas que florecieron en aquellos tiempos escribieron versos más armoniosos, manejaron la lengua con más destreza y expresaron sus pensamientos con más artificio y maestría. Entonces el famoso Lope de Vega manifestó las riquezas de su poesía e hizo resplandecer aquel soberano ingenio de que tan liberalmente le había dotado la naturaleza. No alabaré su excesiva facilidad en componer poemas dramáticos y épicos; no le perdonaré los conceptos sutiles y los juegos de vocablos de que algunas veces se vale, aunque no con tanta frecuencia como creen algunos; pero al mismo tiempo diré que aquella fluidez, dulzura y armonía de versos, aquella variedad y belleza de imágenes, aquella abundancia de sentencias, aquella copia y aquella propiedad de expresiones recompensan muy bien sus defectos y pudieron adquirirle con justo motivo los aplausos no sólo de Espańa, sino de toda la culta Europa (II, pp. 68-69).

¿Dónde se encontrarán versos más armoniosos y suaves, estilo más fluido y nítido, y mayor copia de sentencias y de palabras que en las canciones del tan celebrado Lope de Vega? ¡Ojalá no hubiera querido mancharlas con sutilezas, afectaciones y puerilidades!, que seguramente hubiera sido Lope el príncipe de los líricos españoles, y aun tal vez de todos los modernos (II, pp. 343-344).

A estos elogios del portentoso ingenio de Lope, que repetirá en otros lugares, suma también los de Góngora, Quevedo y Calderón, si bien reconociendo con pesar que siendo los poetas que más habrían podido ilustrar la poesía española fueron los que le ocasionaron mayor daño: «¿Dónde se encontrarán ingenios más vivaces y fecundos para el Teatro que Lope y Calderón? ¿Dónde imaginación más amena y brillante que la de Quevedo? ¿Dónde un ingenio más sublime y elevado que el de Góngora? Pero éstos, introduciendo en la Poesía dramática extrañezas ingeniosas, accidentes complicados y monstruosidades inverisímiles; acumulando en las composiciones jocosas y serias equívocos, conceptos sutiles, expresiones hinchadas, voces desusadas y pensamientos falsos, autorizaron con su ejemplo semejantes defectos e hicieron que tuviesen más lugar entre los poetas españoles viendo que 
los más nobles ingenios los abrazaban»(II, p. 69). Se «corrompió» así la poesía española y ello hizo que el siglo XVII pueda considerarse como «el tiempo de su desolación», aunque no faltaran algunos, como el príncipe de Esquilache, el conde de Rebolledo, Solís o Luis de Ulloa, que supieron sustraerse a ese contagio y conservaron el buen gusto. Pero ellos no son los únicos que merecen su complacencia. La Araucana de Ercilla ocupa el lugar más destacado en la épica, pues aunque no llegó a la excelencia poética de Camoens, "por la novedad de la materia, por haber adornado su poema con algunos buenos pasajes y por haber él mismo tenido parte en la acción que se propuso cantar, ocupa entre los poetas épicos un lugar bastante distinguido», y en menor medida, el Bernardo de Balbuena (II, pp. 129-130); en la épica burlesca, La mosquea de Villaviciosa (II, p. 154); y en la didascálica, las obras conocidas de Lope, la Selva militar y politica del conde de Rebolledo, y particularmente el poema De la pintura de Céspedes, "que puede colocarse entre las poesías clásicas» del género (II, p. 170).

Dentro de la poesía dramática, la especie que materializa «las más altas y sublimes cimas del Parnaso» (II, p. 19), el siglo XVI presenta varias figuras notables: Fernán Pérez de Oliva, magnífico adaptador de la tragedia griega y muy superior a otros trágicos como Virués o Juan de la Cueva, Lope de Rueda, "primer cómico famoso de España», que aunque sólo conoce fragmentariamente piensa que merece alabanza por «la dulzura, naturalidad y sencillez de su estilo», y luego, Alonso de la Vega, Cervantes, Guillén de Castro y otros más, dice someramente, que también cultivaron el teatro y "con sus fatigas lo elevaron a mucho más alto honor» (II, pp. 247-248). A cambio, Torres Naharro le merece un juicio bastante desfavorable. Siguiendo de cerca las ideas de Lampillas, que no su vehemencia vindicativa, observa que a partir de Lope el teatro mudó enteramente de semblante y «se dio principio a una nueva Dramática» que encandiló al público español y recogió los aplausos y elogios de toda Europa. «Vega, Calderón, Castro, Moreto, y todos los cómicos que entonces se celebraban eran españoles, y todas las piezas teatrales que causaban admiración universal, que se traducían en otras lenguas, que se buscaban en todos los teatros, todas eran parto de la vivaz fantasía de los españoles» (II, pp. 24-249). Pero esa dramática exuberante, aunque inequívocamente tiene muchos valores, encierra también notorias irregularidades. Y de ambas cosas, así como de sus semejanzas y diferencias con el teatro inglés y francés, y de las deudas de este último con el español, es de lo que trata básicamente al hablar de ella. Pero, como Lampillas, sin entrar a valorar la obra concreta de los dramaturgos.

No procederá así con los novelistas, de cuatro de los cuales sí que hará comentarios elogiosos. De Cervantes en primer lugar, al que celebra 
calurosamente tanto por el Quijote como por las Novelas ejemplares. Considerándole como el más «ilustre escritor» del género en Espańa, resalta del Quijote «la fecundidad y gentileza de imaginación, la naturalidad y verdad de las narraciones y descripciones, la elegancia y amenidad del estilo", su acierto en ridiculizar las necedades y extravagancias de los libros de caballerías, y «el fino gusto y sano juicio» con que ha sabido formar "de un complejo de extravagantes necedades un libro noble y deleitable, que ha sido recibido con aplauso tan universal de todas las naciones» (II, p. 384). Y de las Novelas ejemplares, para él muy superiores a cualquiera de las modernas, la naturalidad y precisión del relato, el verismo y diversidad de situaciones y caracteres, excelente estructuración, acertado estilo y oportunidad de las reflexiones para hacer ver la conexión de las cosas y dar mayor peso, evidencia e interés a la narración. De ahí nace, apostilla, que «aún después de casi dos siglos se lean y vuelvan a leer por las personas cultas, se reproduzcan en nuevas traducciones y reimpresiones, y se tengan por una obra clásica y magistral en su género» (II, p. 400). Los otros tres que menciona son Gil Polo, cuya Diana enamorada antepone a la de Montemayor, Mateo Alemán, «el cual con su vivaz y fértil fantasía supo inventar tan nuevos y curiosos accidentes, y los expuso con tan buen orden y método, y con estilo tan puro y claro, elegante y ameno que las picardías de su Guzmán ofrecen una agradable lectura con alguna útil doctrina para la sociedad» (II, p. 384), y Quevedo, que en esa misma línea escribió la Vida del gran Tacaño) «con mucha vivacidad acumulando graciosos y picantes pasajes del ingenio picaresco de su héroe», si bien, matiza, excediéndose tanto en equívocos, pensamientos falsos, exageraciones y bajezas que no llegó a la excelencia del estilo y al aire y nobleza histórica que aquél dio a las burlescas acciones de su Guzmán (II, p. 387).

Y en cuanto a la literatura contemporánea, la visión que ofrece a la altura de los primeros 80, antes de que aparezcan los frutos más granados de la literatura dieciochesca, además de sucinta, no es en exceso halagüeña. En el breve apunte que dedica a la lírica, de los tres nombres que menciona sólo merecen un aprecio moderado Luzán («restableció con su esplendor la Lírica espańola escribiendo con estilo correcto y buen gusto») y su compañero de exilio Montengón («escribiendo odas elegantes y sublimes, ha abierto un nuevo camino a los Líricos españoles, que podrán correr con laudable suceso»)»; del otro, el popular García de la Huerta, cree que lamentablemente se ha dejado llevar más por el gusto defectuoso del siglo anterior que por «la sencilla, nativa e igual nobleza de los buenos poetas de su nación». Por lo demás, una nota al pie de su traductor advierte que cuando redactaba estas páginas aún no se habían dado a conocer las poesías de Meléndez Valdés, 
«que las tiene en mucho aprecio y cree que acarrearán honor a España, especialmente las anacreónticas» (II, p. 344). Poco complaciente también con el teatro, reprocha a los dramaturgos su escaso empeño en cultivarlo, pese a estar hoy mucho más extendido "el verdadero gusto" que en el siglo pasado. Ignorando enteramente el teatro popular, el grueso de las obras que menciona, sin demasiado entusiasmo, son tragedias: las dos de Montiano, que aunque correctas, le parecen frías y lánguidas, las tres de Moratín padre, escritas "con alguna regularidad y fuerza trágica», Sancho García de Cadalso, la Numancia destruida de López de Ayala, la Raquel y la versión libre de Agamenón de García de la Huerta, la adaptación de Progne y Filomena de Sebastián y Latre, y Ana Bolena y Sancho García del marqués de Palacios, así como las compuestas por los jesuitas para sus certámenes -Filoctetes, Jonatás, etc.-, «bastante conformes a las leyes del teatro». En cuanto a la comedia, aparte de aludir también a la adaptación de Sebastián y Latre de El parecido en la corte de Moreto, la única que recuerda, con una pincelada elogiosa, es la traducción de Luzán de La razón contra la moda. Pese a reconocer que todos esos autores «y algunos otros» han procurado conducir al pueblo por el buen camino y que sus esfuerzos son dignos de alabanza, considera que ninguna de esas composiciones son "preciosos frutos capaces de mantener la escena española en la posesión de alguna parte del crédito perdido» (II, p. 299). En una posición mucho más destacada coloca al Fray Gerundio de su también compañero de exilio Francisco de Isla, única novela actual que menciona (ya antes la había celebrado Lampillas) y a la que no duda en considerar «un romance clásico y magistral», muy superior a los otros de carácter satírico que se han escrito en Europa. Piensa que aunque podría haber ofrecido una crítica más fina y una más vasta y selecta erudición, nadie podrá negar -en los dos tomos publicados- su originalidad, ingenio, amenidad, y gracia y hermosura de estilo. Por eso, y por «tantos accidentes tan bien ideados y conducidos fácil y espontáneamente, tantas pinturas tan vivas y expresivas, tantos diálogos tan verdaderos y naturales, tantas expresiones tan propias y enérgicas, y tantas otras prendas de invención y de estilo» la reputa como una obra clásica y magistral (II, p. 389). Esa escueta nómina se cierra con las dos conocidas obras de Tomás de Iriarte: el poema didascálico De la música, a su juicio una de las mejores producciones de la poesía moderna, famosa y aplaudida ya en "de toda la culta Europa» (II, p. 171) y las también aplaudidas Fábulas literarias, que aunque sin ser excelentes, deben tenerse «por las más acabadas de cuantas han salido a luz después de las magistrales de La Fontaine» (II, p. 378).

Aquel primer sillar que Sarmiento había puesto en el edificio de la literatura espańola, aumentado, reorientado o ajustado luego por Velázquez, 
los Mohedano y Lampillas, se completaba ahora a lo largo y a lo ancho. Porque no sólo se prolongaba hasta los poetas más recientes; la experiencia poética espańola quedaba encuadrada y valorada en el vasto conjunto de la cultura universal. Y así es como sería estudiada al institucionalizarse como disciplina académica en los Reales Estudios de San Isidro ${ }^{35}$. Todos, de un modo o de otro, y con arreglo a las limitadas posibilidades de los materiales disponibles, habían pretendido abarcarla y levantar el edificio de su historia, o lo que es lo mismo, construir el Parnaso español en su decurso. Muy lejos estaban todavía del escepticismo, incertidumbres y ajuste de cuentas a que se iba a someter esa disciplina en épocas futuras ${ }^{36}$. Ciertamente, la imagen que dibujan se nos puede antojar hoy pobre y escasamente satisfactoria, porque para completar el edificio habrían de rescatarse y de sumarse aún otras muchas piedras, y enfocar el estudio de los autores desde otras muchas perspectivas analíticas. Pero todos, desde un común sentimiento de identidad nacional, quisieron dar fe, y la dieron, de la tradición literaria autóctona, estableciendo en la medida de lo posible y según sus convicciones estéticas un canon de prelaciones. Si comparamos sus valoraciones con las de otros críticos contemporáneos -labor realizada ya en gran medida por Rosa María Aradra y por quienes han estudiado monográficamente la recepción setecentista de autores como Garcilaso, Góngora, Lope, Calderón, etc.advertiremos muchas coincidencias y escasas discrepancias, pues no en vano todos pertenecían a una cultura educada en el clasicismo. Justamente, desde esas convicciones clasicistas, o si se quiere, neoclásicas, consagraron como figuras cimeras del Parnaso a quienes hoy, desde otros presupuestos estéticos, seguimos considerando nuestros clásicos (Garcilaso, fray Luis, Cervantes, Lope, Quevedo, los Argensola, Mateo Alemán, Villegas, etc.).

35. Para la creación y contenido de esa novedosa cátedra de Historia Literaria, vid. José Simón Díaz, Historia del Colegio Imperial de Madrid, Madrid, CSIC-Instituto de Estudios Madrileños, 1959, t. II.

36. Dentro de la oceánica literatura sobre el tema, cabe recordar el reciente volumen sobre Teorías de la historia literaria, introducido y coordinado por Luis Beltrán Almería y José Antonio Escrig, Madrid, Arco /Libros, 2005. 